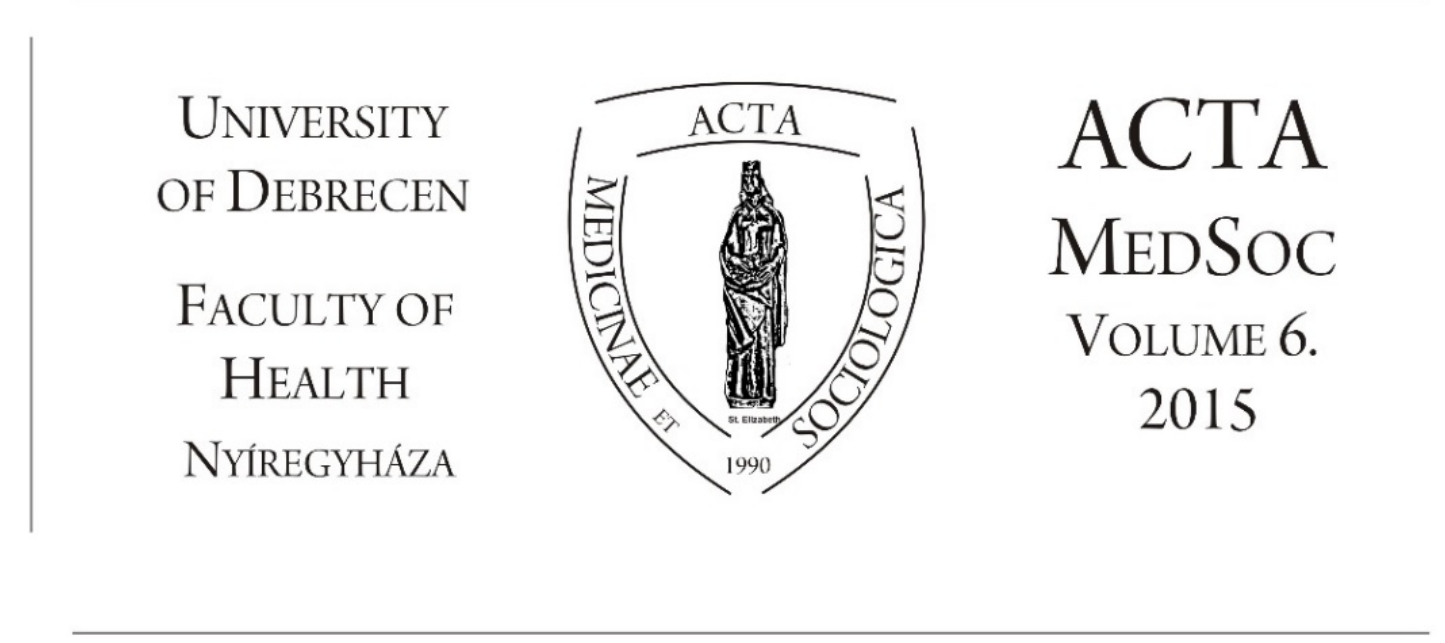

\title{
A szubjektív egészségi állapot tényezői és azok változása Nyíregyházán és vonzáskörzetében
}

\author{
Hüse Lajos \\ Debreceni Egyetem Egészségügyi Kar, Nyíregyháza
}

\begin{abstract}
Changes in Nyiregyhaza and the Surrounding Area and Subjective Health Status. The study conducted in 2015 by the University of Debrecen Faculty of Health and the Social Department of the Nyíregyháza Mayor's Office, based on the $4^{\text {th }}$ cooperative ,quality of life" research, provides an overview of the objective health status, health behavior and those factors affecting the subjective heath of the inhabitants. The research provides the most recent panel survey data and compares these results with earlier findings. The current wave was expanded to include the inhabitants living in villages of the rural region around Nyíregyháza which allowed for comparison of the health status of city and county inhabitants.

Those factors affecting the subjective health status and self perceived health of the inhabitants were the same as panel results from previous years. While the differences did not reach significance, overall those sampled in 2015 reported feeling healthier than was found in previous waves. The data shows that subjective health status is influenced by the respondents' sex, age, highest level of education, marital status, if they suffer from persistent or recurrent diseases, and if they have friends or not. There was a relationship between the respondents' happiness and presupposed health. The second half of the study is restricted to the presentation of the data on the population's health and health behavior.
\end{abstract}


The primary finding is that the rural population's burden of disease appears to be higher than that of the city dwellers while their access to the health care system and services is much more restricted.

Keywords: subjective health status, background effects, longitudinal comparison, health behavior

Az utóbbi évtizedekben az egészségtudomány messze meghaladta azt a felfogást, hogy az egészség lényegében a „,nem-betegség”, azaz pusztán a betegség hiánya. Az egészség mára sokdimenziós fogalom lett, amely a bio-medikális meghatározásokon túl felöleli az életminőség, sőt, a társadalmi beilleszkedés elemeit is. A WHO definíciója szerint ,, az egészség a teljes testi, lelki és szociális jólét állapota, és nem csupán a betegség vagy fogyatékosság hiánya”. Az „egészség” mérésének célja is bővült - a társadalmat alkotó egyének egészségi állapotának feltárása továbbra is elsődleges az egyéni kockázatkezelés támogatása, a szolgáltatás-tervezés, az egészség-politika, vagy a költségvetés sarokszámainak meghatározása szempontjából, de mindinkább tért nyer az a személet, hogy az egészségi állapot mutatóival valójában a társadalmi elörehaladást vagy hanyatlást (progresszió, illetve regresszió) mérjék, szemléltessék. A Debreceni Egyetem Egészségügyi Kara és Nyíregyháza MJV Polgármesteri Hivatal Szociális Osztálya együttmüködésében 2008-tól rendszeresen megvalósuló, városi szintü kutatások eredményei is beilleszthetőek ebbe a multi-dimenzionális keret- és célrendszerbe - noha a 2008, 2010, 2012 és végül 2015-ben lezajlott vizsgálatok csak kisebb részben irányulnak az egészségi állapot feltárására ${ }^{33}$ (Fábián, Kiss, Patyán és Huszti, 2012; Huszti, Patyán, Fábián 2014). Jelen tanulmány a 2015-ös, 4. hullám adataira támaszkodva mutatja be a nyíregyházi lakosság szubjektív egészségi állapotát befolyásoló tényezőket, ugyanezen adatbázis alapján összeveti a városlakók és a vonzáskörzetben élök (egészen pontosan a Nyíregyházi járás lakossága) egészségérzetét, valamint ahol lehetséges, bemutatja a szubjektív egészségi állapot idősoros változásait a korábbi hullámok tükrében.

\section{A sokdimenziós egészségfelfogás és a társadalom viszonya}

Számos empirikus vizsgálat bizonyítja, hogy az egyén egészségét és jóllétét erősen befolyásolja az iskolai végzettség, a foglalkoztatottság, a jövedelem, a státusz, a lakásviszonyok, a tápláló ételekhez való hozzájutás, a megfelelö és hatékony egészségügyi alapellátáshoz való hozzáférés, a genetikai örökség, a korai élettapasztalatok, s természetesen a kulturális és vallási elemek által befolyásolt, életmódbeli tényezők, valamint az egyéni viselkedés (egészségmagatartás, rizikómagatartás). A testi-lelki egészség komplex, ún. szivárvány-modellje (Dahlgren és Whitehead, 1991) ezen empíriák összegzéseképpen fogalmazódott meg. Az

${ }^{33}$ Ez a vizsgálat a TÁRKI felmérésekhez hasonló módszertannal dolgozva kutatja többek között az emberi élet minőségi vonatkozásait. 
Egészségügyi Világszervezet (WHO) olyan nagyszabású programokat koordinál, amelyek a szivárvány-modell egyes szintek egymásra hatásának mechanizmusait tárják fel, a hatékony beavatkozás jó gyakorlatait keresik, illetőleg támpontokat adnak az egészségpolitikában illetékes döntéshozóknak, vagy az egészségpolitikát befolyásolni képes társadalmi mozgalmaknak.

\section{1. ábra. Dahlgren és Whitehead (1991) szivárványmodellje}

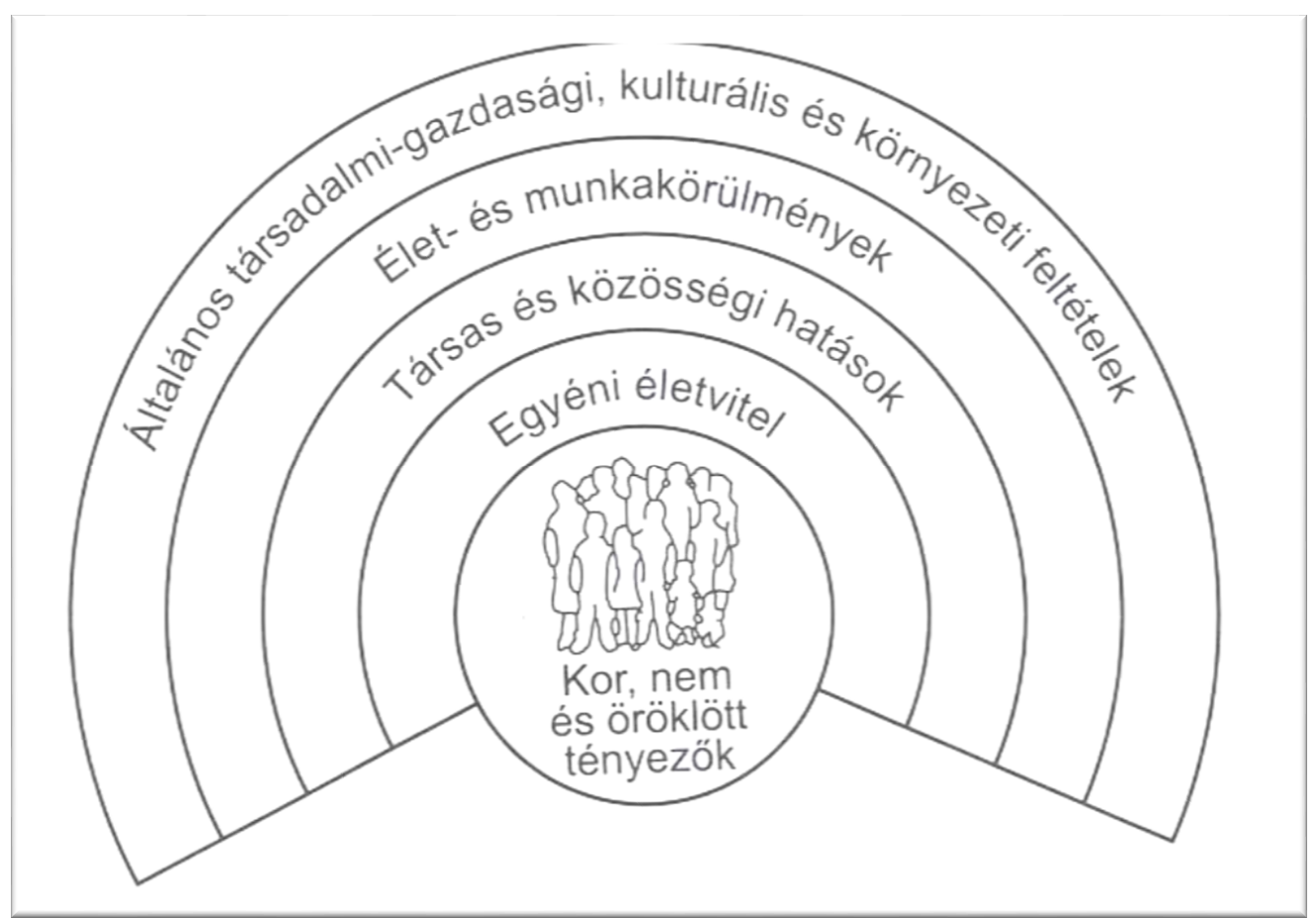

Ez a modell világosan rámutat a legszélesebb társadalmi közegtől az egyén felé haladó befolyásra - a szivárvány minden szférája hatást gyakorol a belsőbb szférákra. Kívülről befelé haladva: a társadalmi feltételek keretében az egyének tömegével rekesztődhetnek ki a lehetőségek felhasználóinak köréből, amennyiben az inklúziós erőfeszítések nem kompenzálják a kirekesztődést. Az elszabaduló egyenlőtlenség és kirekesztődés elsősorban a hátrányos helyzetủek élet- és munkakörülményeiben manifesztálódik, majd a közösségi hatások terén gerjednek tovább, meghatározva az egyének életvitelét, amely a kor, a nem és az öröklött tényezők hatásaival kombinálódva termelik ki az adott mennyiségủ egyénre - mint társadalmi rétegre - jellemző egészségi állapotot, életesélyeket (Dahlgren és Whitehead, 1991).

A Marmot-jelentés, amely az egészség-egyenlötlenségek (health inequities) elleni küzdelem és a WHO egészségpolitikájának sarokpontjává vált, megállapítja, hogy az egészségi állapotbeli egyenlötlenségek csökkentése elsősorban méltányosság és társadalmi igazságosság kérdése. Az a nagyszámú ember, aki minden évben idö elött meghal Angliában az egészségi egyenlötlenségek következtében, összesen mintegy 1,3-2,5 millió évvel hosszabb ideig élhetne. A jelentés rámutat, hogy az egészségi mutatókban társadalmi gradiens figyelhető meg - minél alacsonyabb egy ember társadalmi pozíciója, annál rosszabb az egészségi 
állapota. Ugyanakkor figyelmeztet, hogy ha a beavatkozás kizárólag a leghátrányosabb helyzetűekre fókuszál, az nem fogja hatékonyan csökkenteni az egészségi egyenlőtlenségeket. Ehhez univerzális intézkedésekre van szükség, amelyek léptékének és intenzitásának arányosnak kell lennie a hátrányos helyzet mértékével (Marmot és mtsai, 2010).

Az egyenlőtlenség egyszerre egyéni (kirekesztődés) és társadalmi (kirekesztés) kategória. Az egyének szociális helyzetét láthatjuk úgy is, mint ami túlnyomórészt magán az egyénen múlik (szorgalmán, akaratán, szabad döntésén), és ezzel a felelősség legjavát is erre a szintre szignáljuk, elhanyagolva a társadalmi felelősség elvét egy olyan szociálpolitikát támogatva, amely a lehető legkevesebbet nyújtja a rászorulóknak. Amennyiben viszont a társadalom felelősségét hangsúlyozzuk (társadalmi különbségek, mint determinánsok), levéve ezzel a felelősség terhét az egyénről, egy bőkezüen kompenzáló szociálpolitikát támogatva, azzal az egyén cselekvőkészségét gyengítjük, az ellátórendszerektől való függőségre szocializáljuk, gyengítve a saját életét szervező kompetenciáit (Pikó, 2003). Olyan felfogásra van tehát szükség, amely egyszerre veszi figyelembe az egyén és a társadalom felelősségét és lehetőségeit - és olyan szociálpolitikára, amely kompenzálja a társadalmi hátrányokat, egyúttal kellő mértékben aktivizálja az egyén törekvéseit, fejleszti kompetenciáit (empowerment, esélyerősítés).

Az egészség determinánsai közül nem mindegyik kínál jó lehetőségeket a beavatkozásra, mások viszont jól fejleszthetők. Az egyes determinánsokat megcélzó beavatkozások egymással összefüggö rendszert alkotnak. Számtalan modell hívja fel a figyelmet az egyes determinánsok közötti kapcsolatok fontosságára, illetőleg a cirkuláris viszonyokra, amelyek a rendszerbe kerülő hatásokat mind jobban felerősítik - erre épít Evans és Stoddard (2003) mezö-modellje. Legyen az a társadalmi helyzetből, kirekesztettségből fakadó hátrány, vagy egy váratlan életesemény (tartósan beteg gyermek születése, baleset, stb.), illetve egy jól felépített és pontosan célzott egészségfejlesztő program, a hatása a rendszer számos elemében változást okoz.

2. ábra. Evans és Stoddard (2003) mezö-modelje

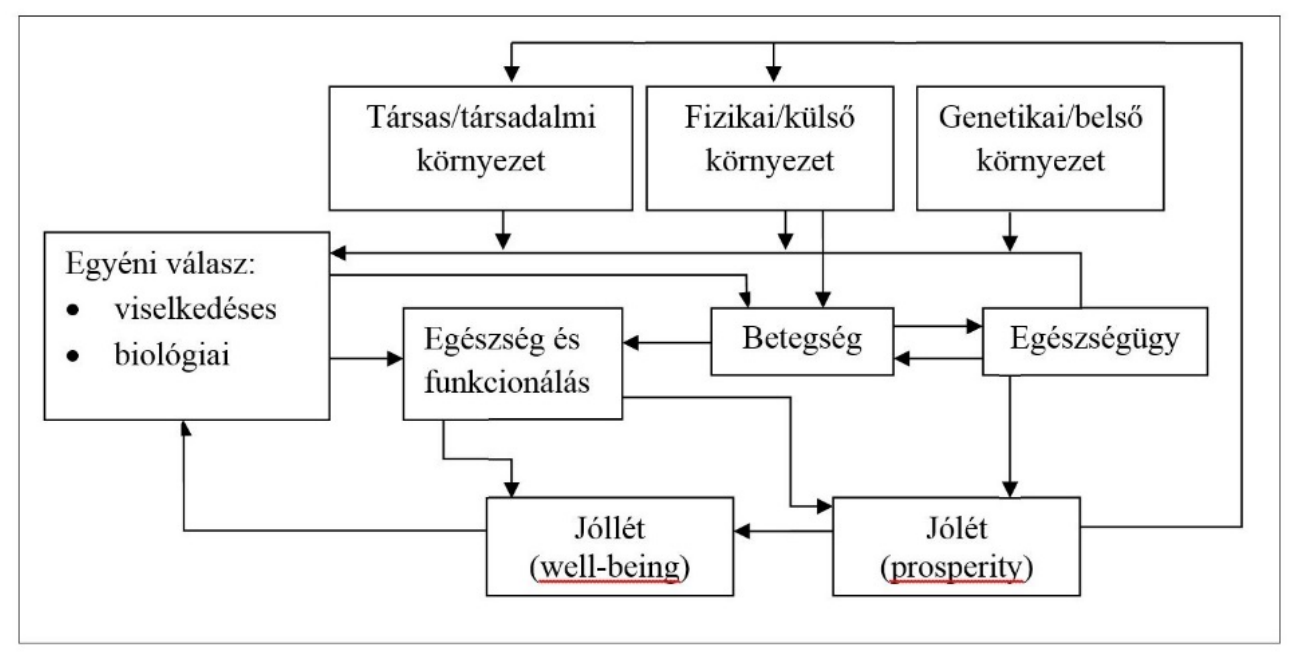




\section{A szubjektív egészségi állapot alkalmazhatósága}

Az egészségi állapot jellemzésére többféle mutatószámot is alkalmazunk. Léteznek módszertanilag jól megalapozott, ún. kemény mutatók, mint például az egyes életkorokban (kiemelten a születéskor, illetve a 65 éves korban) várható élettartam, a halálozási ráták meghatározott halálokonként, az elkerülhető halálozások alakulása vagy a morbiditási adatok. Az objektívnek tekinthető indikátorok mellett léteznek speciális, szubjektív elemeket tartalmazó mérőszámok is, mint amilyen a szubjektív egészségi állapot (avagy vélt egészség mutató, /self/ perceived health), melynek mérésére a WHO ajánlása szerinti ötfokozatú skálát alkalmazzuk (Tokaji, Faragó és Boros, 2011).

A szubjektív egészségi állapot mutatója az egyének önértékelésén alapul és nem feltétlenül függ össze szorosan az orvosi diagnózissal. Az egészség megítélésében kiemelt szerepet játszik az egyén társadalmi, gazdasági helyzete és kulturális gyökerei. A szubjektív egészségi állapot meghatározása a nemzetközi gyakorlatban elfogadott és rendszeresen alkalmazott eszköze a lakossági egészségfelméréseknek (Pikó, 2006). Természetesen nem elhanyagolható a szubjektív megközelítés kritikája; a betegek hamis képet alkothatnak állapotukról (Johnston, Propper és Shields, 2007), sokkal inkább támaszkodnak a referencia-csoportjaikról alkotott képre, mint önmaguk állapotának, érzeteinek megfigyelésére (Kaplan és BaronEpel, 2003), illetve a nemzeti és etnikai különbözőségből fakadó kulturális preferenciák (és viselkedések) eltérősége miatt torzító hatást eredményezhet alkalmazása az összehasonlító vizsgálatokban (Tokaji, Faragó és Boros, 2011). Ugyanakkor vegyük figyelembe, hogy a bio-medikális modell sem kritika nélkül való. Könczei György és Hernádi Ilona megállapítása nem csupán a fogyatékosság bio-medikális modelljének visszáságára mutat rá, de ugyanilyen érvénnyel bír az egészség-modellek terén is. „A medikális modellt alkotó narratívák azzal, hogy a szabályozásra, a normalizálásra helyezik a hangsúlyt, illetve azzal, hogy azt sugallják, uralni, kontrollálni tudjuk a testünket - így csak az orvosokon, a technológián és rajtunk múlik, hogy megelőzzük, adott esetben legyőzzük például a fogyatékosságot -, hamis és korlátolt elvárásokat támasztanak nemcsak a fogyatékossággal élő emberekkel szemben, hanem azoknak az életével szemben is, akik önmagukat nem tartják fogyatékosnak" (Könczei és Hernádi, 2011:6).

Szubjektivitása ellenére a szubjektív egészségi állapot mutatója számos esetben előnyösebb, mint a bio-medikális megközelítések; prediktív funkciói erősebbek, mint a müszeres méréseké (Tahin, Jeges és Lampek, 2000), az egészségi állapot kvalitatív módszerekkel megfogalmazható elemei is feltárulnak (Ware, 1986).

Egy nemzetközi kutatássorozat, a SHARE adatbázisán ${ }^{34}$ végzett elemzés megerősíti, hogy a szubjektív egészségi állapot mérése jól alkalmazható az egyes országok fejlettségének és a lakosság jóllétének kifejezésére (García-Muñoz, Neuman és Neuman, 2014). A közel hatvanezer fös, 50 éves és idősebb egyén adatait

${ }^{34}$ A SHARE (Survey of Health, Ageing and Retirement in Europe) az emberi öregedés legkülönfélébb jellemzőit vizsgálja több tudományág megközelítéséből. A felmérés eddig öt hullámban valósult meg, a hivatkozott tanulmány a negyedik adatgyüjtés eredményeire támaszkodik. 
tartalmazó SHARE adatbázis elemzése alapján a szerzők megállapítják, hogy az objektív egészségi állapot nyilvánvaló hatásán túl a szubjektív egészségi állapot egy sor társadalmi-gazdasági változóval állt világos kapcsolatban. A legerősebb kapcsolat öt, ország-specifikus változóval állt fenn: az egy före jutó GDP; az emberi fejlesztési index (Human Development Index, HDI) ${ }^{35}$; a születéskor várható élettartam önmagában is; az egy före eső egészségügyi kiadások mértéke; valamint a GDP oktatásra fordított aránya. Ezzel szemben a jövedelmi egyenlőtlenségek nem korreláltak szignifikánsan a szubjektív egészségi állapottal. Ahogy a szerzők fogalmaztak, az egészségérzet nem csupán attól függ, hogy „ki vagy te”, hanem attól is, hogy „melyik országban élsz”, hiszen az említett ország-specifikus változók zöme a köz- és szakpolitikák által direkt módon befolyásolt, sőt, irányított. Az eredmények lényegében arra utalnak, hogy a szubjektív egészségi állapotra mind az egyéni, mind az országos szintü beavatkozások, fejlesztések hatást gyakorolnak, ezek a hatások mindkét szinten felhalmozódnak, és erősítik egymást.

Az előnyöket és a hátrányokat egyaránt figyelembe véve megfogalmazhatjuk, hogy a szubjektív egészségi állapot mutatói talán kevésbé alkalmasak a gyógyító beavatkozások bizonyíték alapú (evidence based) megalapozására, ugyanakkor alkalmazásukkal erösödhet az orvos-beteg kapcsolat, a kvalitatív jellegü információk alkalmasak a morbiditás és mortalitás elörejelzésére, és jól beilleszthetőek az egészségről alkotott multi-dimenziós képbe. Továbbá egészen biztosan alkalmas a szubjektív egészségi állapot arra, hogy a társadalmi progressziót, illetve regressziót szemléltessék. A szubjektív egészségi állapot és az azt befolyásoló tényezők feltárása föképpen ez utóbbi aspektusában válik a nyíregyháziak életminőségére irányuló panelkutatás lényegi részévé.

\section{Az egészség szubjektív érzetének alakulása a nyíregyházi panelvizsgálatban}

A szubjektív egészségi állapot mérésére a nyíregyházi panelkutatás a WHO ajánlása szerinti ötfokozatú skálát alkalmazza, amely a megkérdezettek vélelmezett egészségre irányul. A kérdés a panelkutatás eddigi összes hullámának részét képezte (Jóna és Erdei, 2012; Erdei, Fedor és Madácsi, 2014). Az aktuális, 4. hullám azonban számos olyan változást hozott a kutatási szériában, amelyekre az idősoros adatok elemzésekor, értelmezésekor tekintettel kell lenni. Ezen változások legfontosabbjai az 1) új panel-minta, a 2) minta kiterjesztése a járásra és az 3) új kérdések, kérdéscsoportok, amelyek az egészségérzet háttérváltozóiként (is) kezelhetőek (lásd Huszti, 2015a).

Az egészségérzet nyíregyházi trendjét vizsgálva (3. ábra) rögtön szembetünik, hogy a város lakosságát reprezentáló mintában, a vizsgált időszakban egyenletesen nő azoknak az aránya, akik önmagukat nagyon jó egészségi állapotúnak definiálták, igaz, a minta egészéhez képest lényegében nem nő az arányuk, amely 10\% körül mozog. Az önmagukat jó egészségi állapotúnak érzők aránya a korábbi hullámok

${ }^{35}$ Az M. ul Haq és A. Sen által 1990-ben kidolgozott komplex mutatószám demográfiai (születéskor várható élettartam), oktatási (a 15 éven felüliek írni-olvasni tudása; iskolázottsági arány) és gazdasági (vásárlóerő-paritás egy före eső GDP-ben kifejezve) változókon alapul (Husz, 2001). 
során csökkent, miközben nőtt azok aránya, akik elfogadhatónak becsülték az egészségüket - ehhez a tendenciához képest az új mintán megvalósuló 4 . hullám városlakó válaszadói között megnőtt azok aránya, akik jónak, és csökkent azok aránya, akik elfogadhatónak érezték az egészségüket. A megkérdezettek nagyjából tizede minden hullámban rossznak minősítette az egészségét, az arányuk a 2010-es csúcs óta folyamatosan csökken. Nagyon rossznak a minta igen kis része érzékelte állapotát, és a fél százalékpontnyi csökkenésre sem szabad messzemenő megállapításokat tenni.

A 2015-ös hullám kiegészült egy járási mintával, melyről a vizsgált mutatót tekintve megállapíthatjuk, hogy a számottevő arányban megjelenő válaszok esetében (,rossz”-tól a „nagyon jó”-ig) határozott különbség rajzolódik ki a nyíregyházi lakosság önértékeléséhez képest, miszerint a nem nyíregyházi lakosságot reprezentáló válaszadók nagyobb arányban érzékelték egészségüket rossznak és elfogadhatónak, s kisebb arányban jónak és nagyon jónak, mint a nyíregyháziak.

3. ábra. A szubjektív egészségi állapot alakulása, 2008-2015, \%

\begin{tabular}{|c|c|c|c|c|c|c|}
\hline \multirow{10}{*}{\multicolumn{2}{|c|}{$\begin{array}{r}50,0 \\
45,0 \\
40,0 \\
35,0 \\
30,0 \\
25,0 \\
20,0 \\
15,0 \\
10,0 \\
5,0 \\
0,0\end{array}$}} & & & & & \\
\hline & & & & & & \\
\hline & & & & & & \\
\hline & & & & & & \\
\hline & & & & 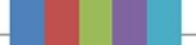 & & \\
\hline & & & & & & \\
\hline & & & & 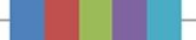 & 1 & \\
\hline & & & & 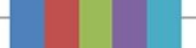 & & \\
\hline & & 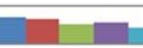 & & & & \\
\hline & & $\begin{array}{c}\text { nagyon } \\
\text { rossz }\end{array}$ & rossz & elfogadható & jó & nagyon jó \\
\hline & 2008 & 3,4 & 10,6 & 38,9 & 37,5 & 9,7 \\
\hline & 2010 & 3,3 & 12,0 & 43,0 & 33,5 & 9,8 \\
\hline & 2012 & 2,6 & 10,0 & 44,1 & 32,9 & 10,4 \\
\hline & 2015-város & 2,8 & 8,2 & 39,7 & 36,1 & 10,9 \\
\hline & 2015-járás & 2,1 & 13,8 & 42,2 & 32,6 & 8,4 \\
\hline
\end{tabular}

Forrás: Nyíregyháza Életminősége 2008, 2010, 2012, 2015

\section{A szubjektív egészségi állapotot befolyásoló tényezők}

$\mathrm{Az}$ egészség önértékelését befolyásoló tényezők esetében vizsgálom azokat a háttérváltozókat, amelyeket a korábbi hullámokban vizsgáltak, valamint beemelek újabb háttérváltozókat is, köztük olyat, amely 2015-ben került be először a battériába. Tekintettel a tanulmány terjedelmi kereteire, a járási adatokra itt már külön nem térek ki. A 2008, 2010, 2012. évi hullámok összesített adatait Jóna és Erdei (2012) valamint Erdei, Fedor és Madácsi (2014) tanulmányaiból merítettem. Miután az említett tanulmányok a szubjektív egészségi állapot ötfokozatú változóját a szélsőértékek összevonásával háromfokozatúként mutatták be, az idősoros adatok összevetésekor jelen tanulmány is összevontan ábrázolja az aktuális dimenziókat, 
míg a 2015-ös hullám adatainál megtartja az eredeti, WHO-ajánláson alapuló ötfokozatú változót.

Az alapvetőnek tekinthető nem, kor, iskolai végzettség, családi állapot háttérváltozókon ${ }^{36}$ túl fontos lett volna az etnikai háttérváltozói vizsgálata is, ez azonban a 2015-ös mintán nem számolható (721 magyar vs. 1 német, 1 román, 7 roma). Ugyancsak kizártuk a vizsgálat alól a jövedelmet, miután a válaszadók egyötöde adta meg az erre vonatkozó adatot.

A korábbi hullámok adatai arra utaltak, hogy a szubjektív egészségi állapotukat rossznak, illetve nagyon rossznak tartók körében a nők aránya magasabb a férfiakénál, míg a nemek aránya pont fordítva alakul a skála másik végén, a jó és nagyon jó egészségérzettel rendelkezők körében. A 2015-ös adatok beilleszkednek ebbe a képbe; határozottan kijelenthető, hogy a nők általában véve rosszabbnak, a férfiak pedig jobbnak érzékelik az egészségi állapotukat, illetve a nemek közötti eltérés szignifikáns 2015-ben $\left(\mathrm{Khi}^{2} \mathrm{p}=0,054\right.$; df=4).

\section{4. ábra. A szubjektív egészségi állapot alakulása nemek szerint, 2015}

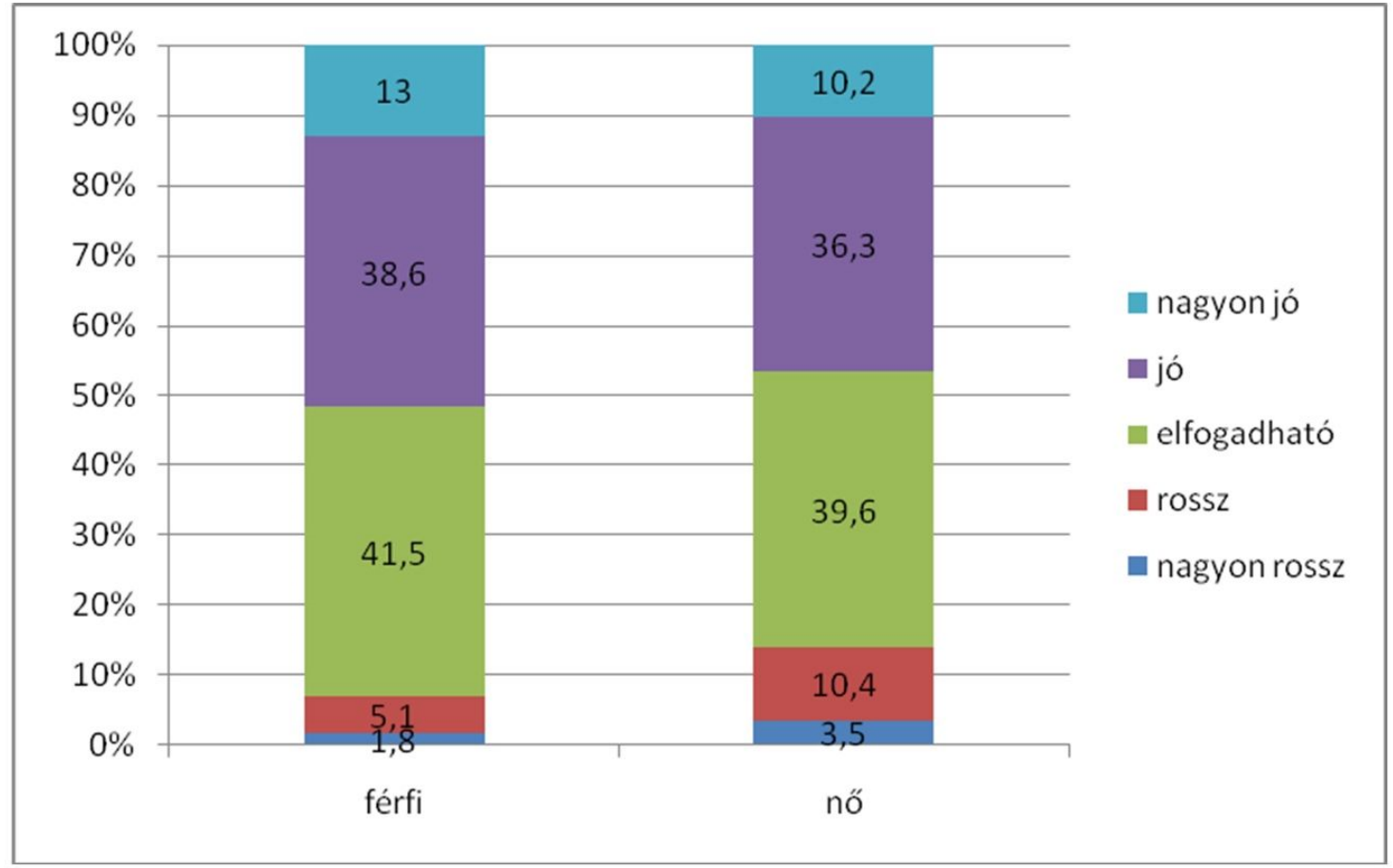

Forrás: Nyíregyháza Életminősége 2015

A nyíregyházi adatokat a 2009., illetve 2014. évi Európai lakossági egészségfelmérés (ELEF) hazai adataival összevetve megállapítható, hogy a nyíregyházi lakosság a hazai lakossághoz képest kevésbé jónak értékelte egészségi állapotát. A magyar adatok alapján 2009-ről 2014-re mindkét nem esetében nőtt (férfiaknál 59-ről 65\%-ra, nőknél 50-ről 58\%-ra) a saját egészségükről pozitívan, és csökkent (férfiaknál 12-röl 10\% alá, nőknél 17-röl 12\%-ra) a negatívan nyilatkozók

\footnotetext{
${ }^{36}$ A demográfiai változó megoszlásáról részletese képet ad Malakucziné Póka Mária (2015) jelen kötetben szereplö tanulmánya.
} 
aránya (Statisztikai Tükör, 2015). Az 5. ábrán látható, hogy Nyíregyházán mindkét nemben lényegesen alacsonyabb arányban találhatóak meg azok, akik jónak (nagyon jó + jó) ítélik meg az egészségüket - ugyanakkor az egészségüket rossznak ítélő férfiak kevesebben, a nők csak valamivel többen vannak, mint az országos mintában.

5. ábra. A szubjektív egészségi állapot alakulása nemek szerint, 2008-2015

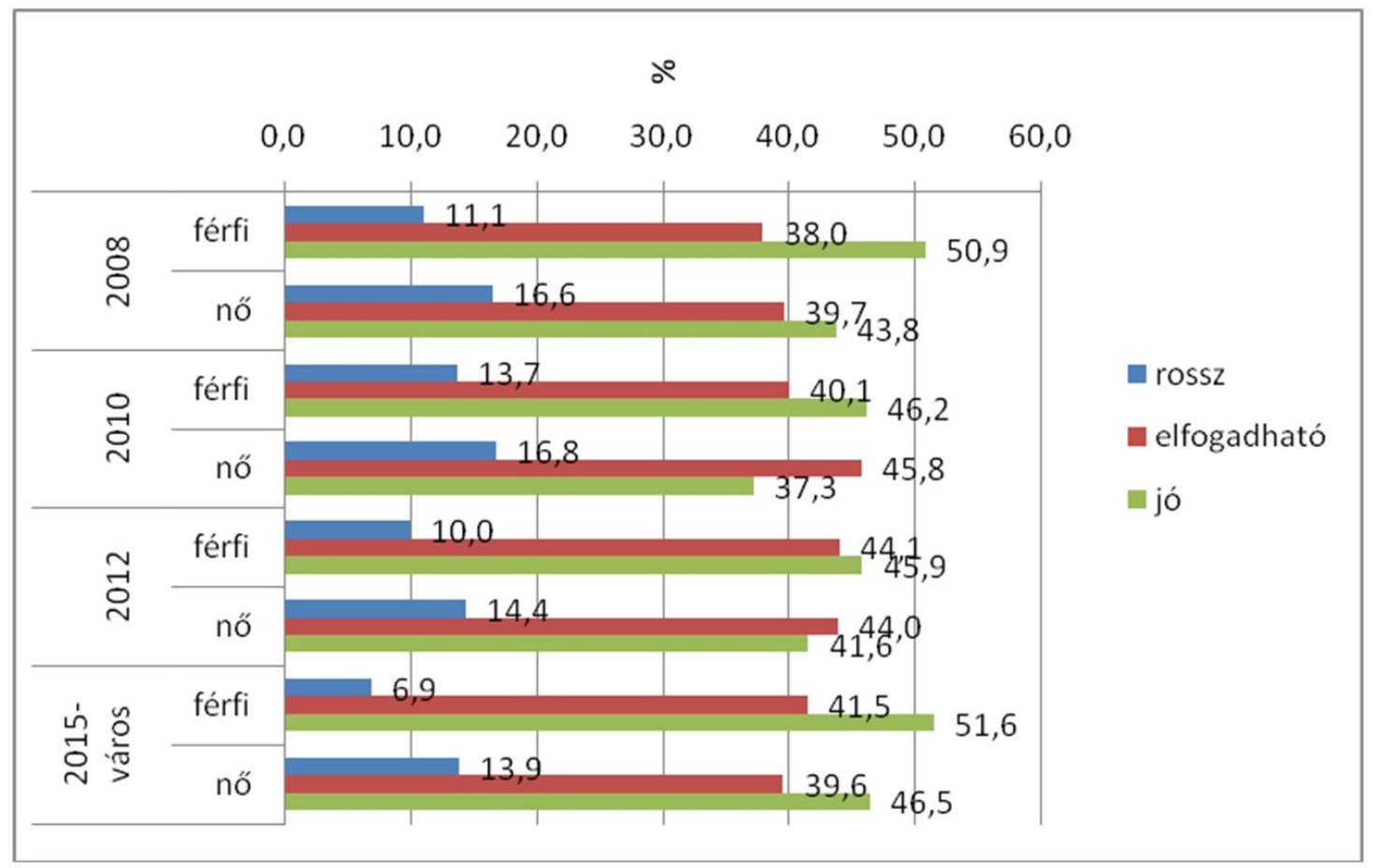

Forrás: Nyíregyháza Életminösége 2008, 2010, 2012, 2015

A korábbi és jelenlegi mintákat korcsoport szerint vizsgálva ugyancsak megállapítható, hogy főbb vonalakban nem változott a nyíregyházi helyzetkép: a legfiatalabbak lényegesen jobbnak minősítik egészségüket, a legidősebbek lényegesen rosszabbnak, mint a többi korcsoport, illetve a szubjektív egészségi állapot a kor elörehaladtával egyre romlik (2015-ben Khí ${ }^{2} \mathrm{p}=0,000 ; \mathrm{df}=20$ ). 
6. ábra. A szubjektív egészségi állapot alakulása korcsoportok szerint, 2015

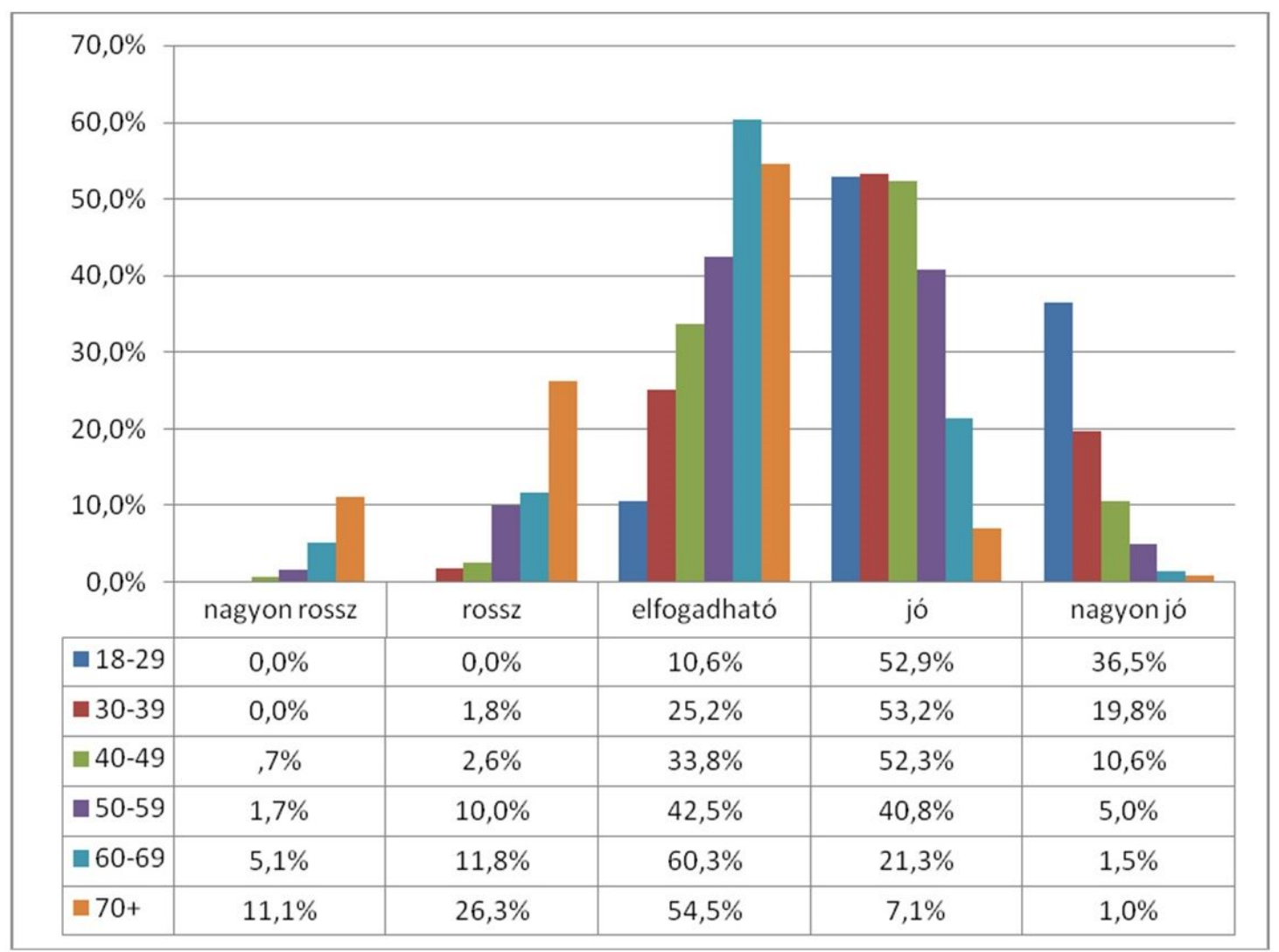

Forrás: Nyíregyháza Életminősége 2015

1. táblázat. A szubjektív egészségi állapot alakulása korcsoportok szerint, 2008-2015 (\%)

\begin{tabular}{|c|c|c|c|c|c|c|c|c|c|c|c|c|}
\hline & \multicolumn{3}{|c|}{2008} & \multicolumn{3}{|c|}{2010} & \multicolumn{3}{|c|}{2012} & \multicolumn{3}{|c|}{ 2015-város } \\
\hline & $\begin{array}{l}v \\
W \\
0 \\
0\end{array}$ & 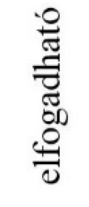 & $: ㅇ$ & 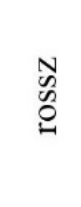 & 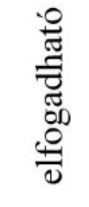 & 으 & $\begin{array}{l}\text { N } \\
\text { Dे } \\
\text { D. }\end{array}$ & 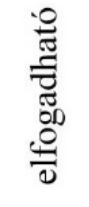 & $: ㅇ$ & $\begin{array}{l}N \\
W \\
0 \\
0 \\
0\end{array}$ & 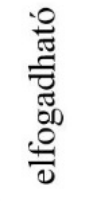 & 으. \\
\hline $18-29$ & 1,1 & 15,6 & 83,3 & 3,1 & 16,5 & 79,3 & 0,8 & 12,4 & 86,8 & 0,0 & 10,6 & 89,4 \\
\hline $30-39$ & 3 & 22,5 & 74,5 & 3 & 27,6 & 69 & 2,4 & 26,6 & 71,0 & 1,8 & 25,2 & 73,0 \\
\hline $40-49$ & 7,6 & 38,2 & 54,1 & 5,3 & 40,5 & 54,1 & 4,1 & 42,1 & 53,8 & 3,3 & 33,8 & 62,9 \\
\hline $50-59$ & 23,8 & 46,6 & 29,6 & 16,8 & 58 & 24,7 & 16,3 & 51,4 & 32,3 & 11,7 & 42,5 & 45,8 \\
\hline $60-69$ & 14,6 & 65,7 & 19,8 & 29,2 & 60,9 & 9,9 & 23,9 & 62,4 & 13,7 & 16,9 & 60,3 & 22,8 \\
\hline $70+$ & 44,4 & 48,1 & 7,5 & 42,2 & 43,8 & 14 & 31,5 & 59,1 & 9,4 & 37,4 & 54,5 & 8,1 \\
\hline
\end{tabular}

Forrás: Nyíregyháza Életminösége 2008, 2010, 2012, 2015

Az egyes hullámokban mért adatok hasonló trendet mutatnak az életkor függvényében, amelybe a 2015-ös városi adatok részben belesimulnak (1. táblázat). A korábbi mérések által kirajzolt trendből a 2015-ös vizsgálat 40-49 éves és 50-59 éves korcsoportjai lógnak ki. A 40-49 éves korcsoport tagjai közel 10 százalékponttal nagyobb mértékben vallották az egészségüket jónak (62,9\%), mint a 
korábbi évek ugyanezen korcsoportjának tagjai (esetükben 53,8-54,1 \% közé esett a jó szubjektív egészségnek örvendők aránya). Az 50-59 évesek szintén jelentősebb arányban (13-21 százalékpont) érezték magukat jó egészségünek a 2015-ös mintában (45,8\%), mint a korábbi minták hasonló korú csoportja (24,7\%-tól 32,3\%ig), továbbá alacsonyabb arányban (5-12 százalékpont) vallották magukat rossz egészségünek (11,7\%), mint a megelőző hullámok azonos korcsoportjában (16,3\%tól 23,8\%-ig). Jelentősen kisebb a 60-69 évesek korcsoportjában azok aránya, akik rossznak vallották az egészségüket, mint a 2010 és 2012-es hullámok azonos korcsoportjában, ám itt a korábbi hullámok trendjét megtöri a 2008-as minta 60-69 éveseinek szubjektív egészségérzete is, amely esetében a rossz egészséget észlelők aránya még a 2015-ös hullám nyíregyházi almintájának azonos arányánál is kisebb.

7. ábra. A szubjektiv egészségi állapot alakulása iskolai végzettség szerint, 2015

\begin{tabular}{|c|c|c|c|c|c|}
\hline \multicolumn{6}{|l|}{$70,0 \%$} \\
\hline \multicolumn{6}{|l|}{$60,0 \%$} \\
\hline \multicolumn{6}{|l|}{$50,0 \%$} \\
\hline \multicolumn{6}{|l|}{$40,0 \%$} \\
\hline \multicolumn{6}{|l|}{$30,0 \%$} \\
\hline \multicolumn{6}{|l|}{$20,0 \%$} \\
\hline $10,0 \%$ & & & & & \\
\hline $0,0 \%$ & nagyon rossz & rossz & elfogadható & jó & nagyon jó \\
\hline — 8 általános alatt & $17,6 \%$ & $17,6 \%$ & $58,8 \%$ & $5,9 \%$ & $0,0 \%$ \\
\hline - 8 általános & $6,6 \%$ & $18,0 \%$ & $45,9 \%$ & $23,0 \%$ & $6,6 \%$ \\
\hline I szakmunkásképző & $4,8 \%$ & $16,4 \%$ & $43,2 \%$ & $30,1 \%$ & $5,5 \%$ \\
\hline - szakközépiskolai érettségi & $2,0 \%$ & $9,1 \%$ & $54,5 \%$ & $24,2 \%$ & $10,1 \%$ \\
\hline घimnáziumi érettségi & $2,8 \%$ & $3,7 \%$ & $40,4 \%$ & $38,5 \%$ & $14,7 \%$ \\
\hline $\begin{array}{c}\text { érettségit követő } \\
\text { szakképzés, technikum }\end{array}$ & $1,3 \%$ & $5,0 \%$ & $35,0 \%$ & $50,0 \%$ & $8,8 \%$ \\
\hline főiskola, alapképzés & ,7\% & $2,9 \%$ & $29,5 \%$ & $49,6 \%$ & $17,3 \%$ \\
\hline I egyetem mesterképzés & $0,0 \%$ & $5,8 \%$ & $30,8 \%$ & $46,2 \%$ & $17,3 \%$ \\
\hline doktori fokozat & $0,0 \%$ & $0,0 \%$ & $40,0 \%$ & $60,0 \%$ & $0,0 \%$ \\
\hline
\end{tabular}

Forrás: Nyíregyháza Életminősége 2015

A 2015-ös városi adatok azt mutatják, hogy a szubjektív egészségi állapot alakulását erőteljesen befolyásolja a megkérdezettek legmagasabb iskolai végzettsége (Khí ${ }^{2}$ $\mathrm{p}=0,000 ; \mathrm{df}=32$ ). A magasabb iskolai végzettségüek rendre ritkábban jellemezték nagyon rossznak, vagy rossznak, illetve nagyobb arányban érzékelték jónak és nagyon jónak az egészségüket, mint a náluk alacsonyabb végzettséggel rendelkezők (7. ábra). A trendtől leginkább az érettségi utáni képzésben (pl. technikum) végzettséget szerzettek különülnek el, miután nagyobb arányban érzékelték rossznak, és kisebb arányban jónak, illetve nagyon jónak az egészségüket, mint a hozzájuk „közeli” szintü végzettségúek. 
8. ábra. A szubjektív egészségi állapot alakulása iskolai végzettség szerint, 2008$2015(\%)$

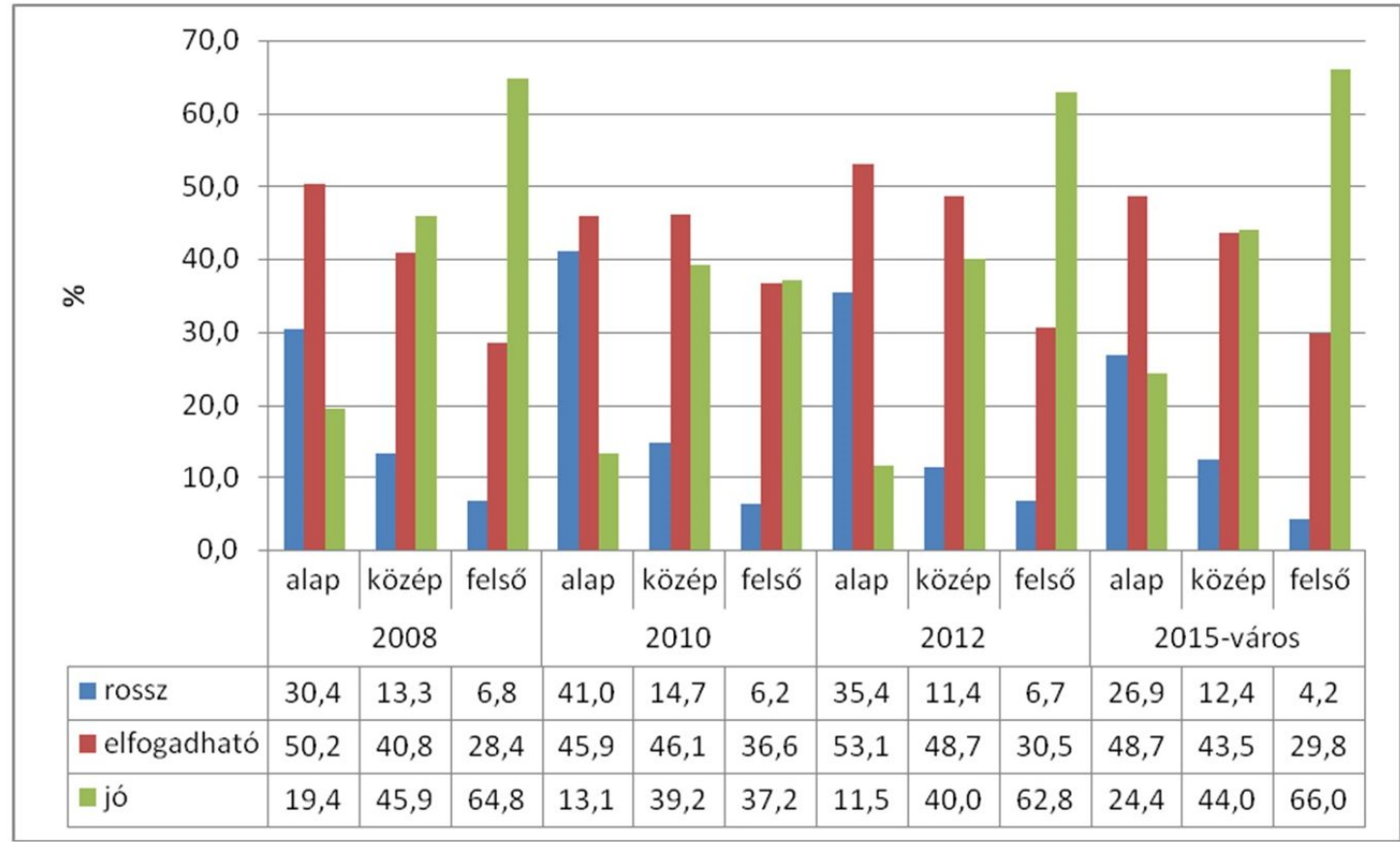

Forrás: Nyíregyháza Életminősége 2008, 2010, 2012, 2015

9. ábra. A szubjektív egészségi állapot alakulása családi állapot szerint, 2015

\begin{tabular}{|c|c|c|c|c|c|}
\hline \multicolumn{6}{|l|}{$60,0 \%$} \\
\hline \multicolumn{6}{|l|}{$50,0 \%$} \\
\hline \multicolumn{6}{|l|}{$40,0 \%$} \\
\hline \multicolumn{6}{|l|}{$30,0 \%$} \\
\hline \multicolumn{6}{|l|}{$20,0 \%$} \\
\hline \multicolumn{6}{|l|}{$10,0 \%$} \\
\hline $0,0 \%$ & $\begin{array}{l}\text { nőtlen, h } \\
\text { ajadon }\end{array}$ & házas & $\begin{array}{c}\text { élettárss } \\
\text { al él }\end{array}$ & elvált & özvegy \\
\hline nagyon rossz & $0,0 \%$ & $1,9 \%$ & $1,5 \%$ & $10,0 \%$ & $8,4 \%$ \\
\hline rossz & $2,0 \%$ & $7,6 \%$ & $2,9 \%$ & $7,5 \%$ & $23,2 \%$ \\
\hline " elfogadható & $14,1 \%$ & $43,8 \%$ & $32,4 \%$ & $45,0 \%$ & $53,7 \%$ \\
\hline घjó & $52,5 \%$ & $39,3 \%$ & $42,6 \%$ & $27,5 \%$ & $12,6 \%$ \\
\hline nagyon jó & $31,3 \%$ & $7,3 \%$ & $20,6 \%$ & $10,0 \%$ & $2,1 \%$ \\
\hline
\end{tabular}

Forrás: Nyíregyháza Életminősége 2015 
A családi állapot függvényében is megfigyelhetőek bizonyos szabályszerüségek az észlelt egészségi állapotot illetően ( $\left.\mathrm{Kh}^{2}{ }^{\mathrm{p}} \mathrm{p}=0,000, \mathrm{df}=16\right)$. Az elváltak és különösen az özvegyek nagyobb arányban érzékelik rossznak és nagyon rossznak az egészségüket, mint a többi csoport. A nőtlenek/hajadonok nagyobb arányban érzik jónak és nagyon jónak az egészségüket, mint a többi csoport (9. ábra). Ez a két jelenség azonban erősen korfüggő - a nőtlenek/hajadonok fiatalabbak, mint a populációs átlag, az özvegyek idősebbek -, így a kimutatott különbség csak részben a családi állapottól függ.

További jellemzőként megemlíthető, hogy a házasok inkább elfogadhatónak tartják egészségüket, és kevésbé jónak, nagyon jónak, ezzel szemben az élettársi kapcsolatban élők inkább jónak, és kevésbé elfogadhatónak, illetve nagyon jónak élik meg egészségi állapotukat. A jelentős különbségnek lehet oka a családi állapot, azaz értelmezhetjük úgy, hogy az élettársi kapcsolat protektívebb az egészségi állapotot tekintve, mint a házasság, csakhogy itt is figyelembe kell vennünk az életkor erőteljes befolyásoló hatását. A mintánkban ugyanis az élettársi kapcsolatban élők 20,3\%-a 18-29 éves, továbbá a 43,5\%-a 30-39 éves, míg a házasok esetén e két életkori csoport aránya csupán 2,6\% és $15,4 \%$ - azaz az élettársi kapcsolatban élők lényegesen fiatalabb csoportot alkotnak, mint a házasok.

10. ábra. A szubjektiv egészségi állapot alakulása aszerint, hogy szenved-e visszatérö betegségekben a megkérdezett, 2015

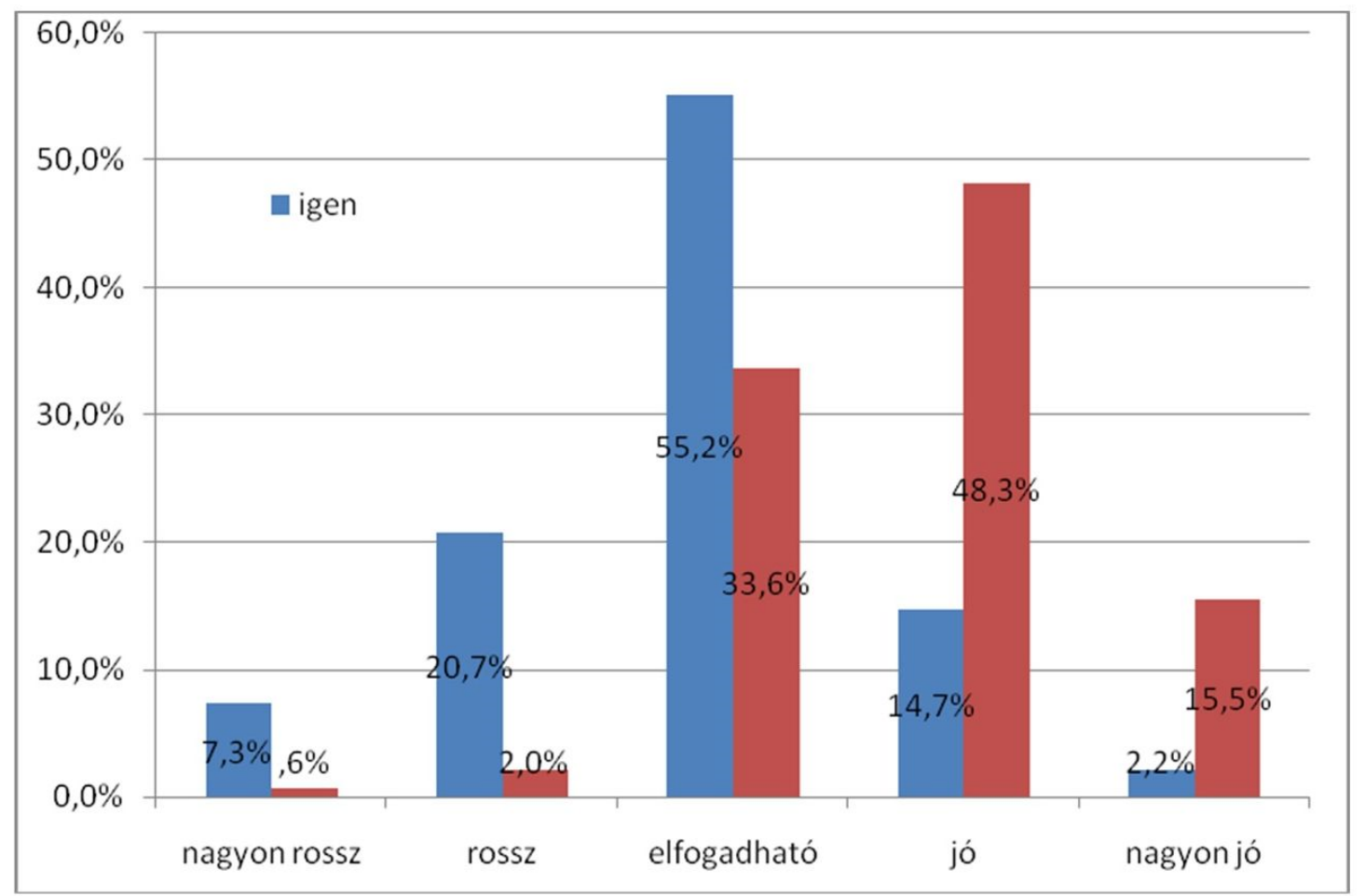

Forrás: Nyíregyháza Életminősége 2015

Bár a szakirodalomban kifejeződnek azok a vélemények is, amelyek szerint a szubjektív egészségi állapot nem jó indikátora az objektív, mérhető 
egészségességnek (lásd a tanulmány elméleti háttérre fókuszáló részét), a 2015-ös hullám nyíregyházi mintájában megfigyelhető az erős kapcsolat az észlelt egészség és aközött, hogy van-e visszatérő betegsége a megkérdezetteknek (Khí ${ }^{2} \mathrm{p}=0,000$, $\mathrm{df}=4)$. A visszatérő betegségben szenvedők csoportja alapvetően elfogadhatónak észleli egészségét, ezen kívül inkább rossznak, mint jónak, míg azok, akik nem számoltak be visszatérő betegségekről, alapvetően jónak érzik egészségi állapotukat, jóval kevesebben elfogadhatónak, illetve jónak (10. ábra).

A barátok számát tekintve a legszembetünőbb törésjellemző, hogy van-e barátja a megkérdezettnek (11. ábra). A baráttal egyáltalán nem rendelkezők az egészségüket inkább elfogadhatónak ítélték meg (52,1\%), negyedük (nagyon) rossznak, 22,9\%-uk (nagyon) jónak. A baráttal rendelkezők ennél lényegesen pozitívabban ítélték meg az egészségüket. Legpozitívabban azok minősítették az egészségi állapotukat, akik 6-50 baráttal rendelkeznek ${ }^{37}$.

11. ábra. A szubjektiv egészségi állapot alakulása a barátok száma szerint, 2015

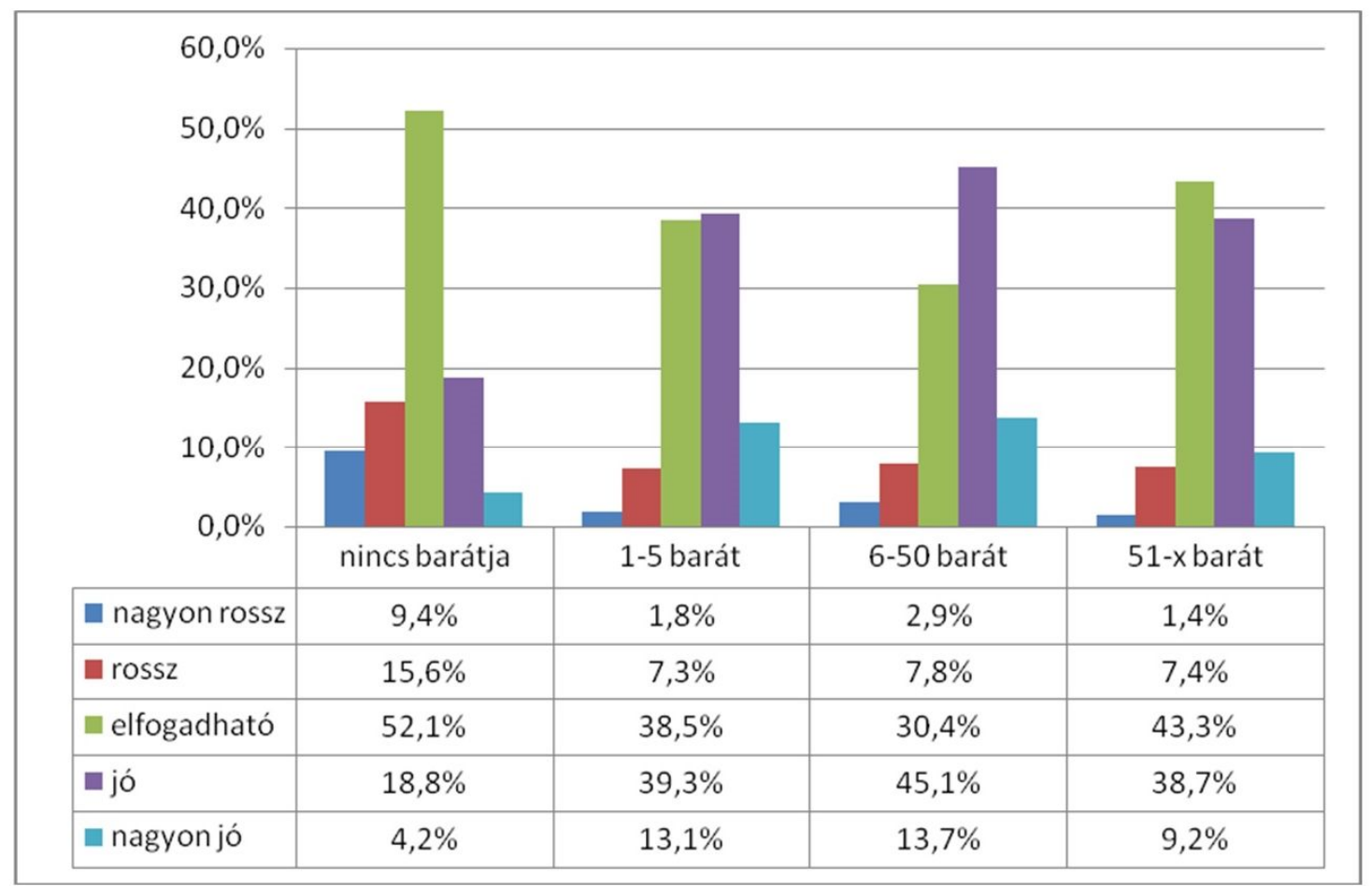

Forrás: Nyíregyháza Életminősége 2015

${ }^{37}$ A minta társas kapcsolatainak elemzését, a barátságok alakulását a kötetben Huszti Éva (2015b) mutatja be. 
12. ábra. A szubjektív egészségi állapot alakulása az Oxfordi Boldogságmérö

Kérdöíven (OWB) elért pontszám szerint, 2015

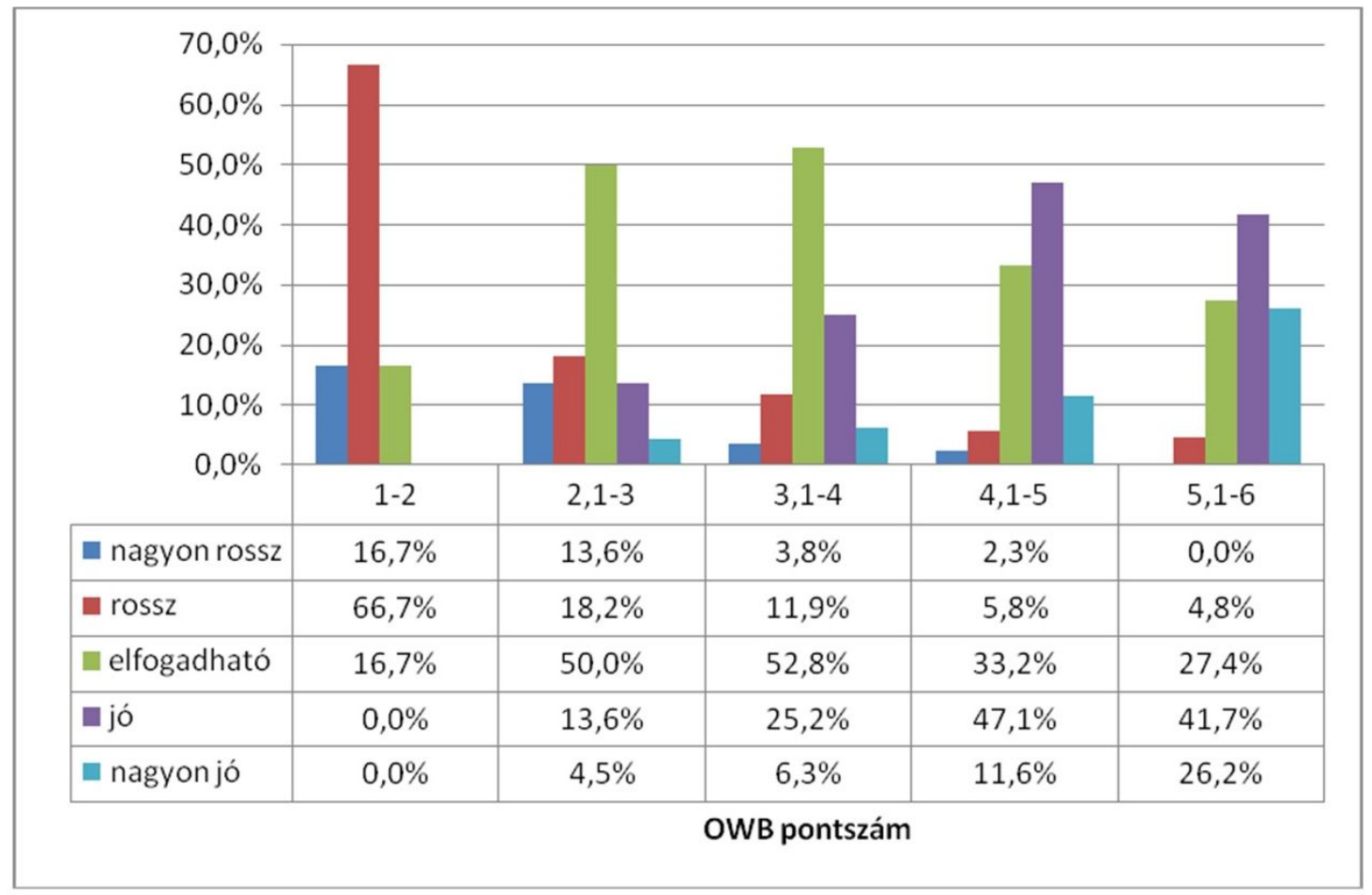

Forrás: Nyíregyháza Életminősége 2015

A nyíregyházi életminőség-kutatás 4. hullámának új elemeként bekerült az Oxfordi Boldogságmérő Kérdőív (OWB), mely 29 kérdés mentén, hatfokú skálán méri fel a megkérdezett lelkiállapotát, melyet 1 és 6 közé eső értékkel jellemez (Szigeti, Fábián és Takács, 2015). Minél nagyobb az érték, annál boldogabbnak mérte a válaszadót a teszt. A vizsgálat eredményei szoros összefüggést mutatnak az OWB-n elért pontszám és a szubjektív boldogság között; minél jobb pontszámú csoportot vizsgálunk, annál inkább javul a vélelmezett egészség (12. ábra). Így például az OWB-n 2 pontot, vagy az alatti értéket elérök csoportjában kiemelkedően magas azok aránya, akik rossznak ítélik az egészségüket (66,7\%), a 2,1-3 és a 3,1-4 közötti boldogság-értéket elérők csoportjának zöme elfogadhatónak, míg a 4,1-5 és az 5,16 boldogság-értéket elérők csoportjának zöme jónak érzi az egészségi állapotát.

\section{A lakosság egészségi állapota}

A lakosság objektív egészségi állapotát a minta tagjainak önbeszámolói alapján vizsgálhatjuk, azaz az eredmények értékelése során figyelembe kell venni, hogy az egyes betegségtípusok előfordulási gyakorisága a megkérdezettek tudásán, emlékezetén, illetve nyilatkozási hajlandóságán alapul. Az egészségi állapot 2015ös hullámban mért adatait Nyíregyháza és a járási alminta összevetésével közöljük.

A városi, illetve járási lakosság közel azonos mértékben szenved állandó, vagy kisebb visszatérő betegségekben. A nyíregyháziak 32,1\%-a, a járásiak 35,9\%-a 
számolt be arról, hogy ilyen betegséggel kénytelen együtt élni. Öket az alábbiakban „,beteg”-ként említjük.

A betegek a kérdőív következő részében egy-három betegségüket megnevezve a betegség súlyosságát is jellemezhették, méghozzá olyan módon, hogy megadhatták, a) szorulnak-e kórházi ápolásra a betegség miatt, b) ágyhoz kötöttek-e otthonukban, c) nem kötöttek ágyhoz, de a munkájukat nem tudják ellátni és d) csak valamilyen szinten korlátozza munkájukban őket a betegség.

2. táblázat. Betegségkövetkezmények Nyíregyházán és a járási lakosság körében, $2015(\%)$

\begin{tabular}{|l|c|c|c|c|c|c|}
\hline \multirow{2}{*}{} & \multicolumn{2}{|c|}{$\begin{array}{c}\text { elsőként említett } \\
\text { betegség }\end{array}$} & \multicolumn{2}{c|}{$\begin{array}{c}\text { másodikként } \\
\text { említett betegség }\end{array}$} & \multicolumn{2}{c|}{$\begin{array}{c}\text { harmadikként } \\
\text { említett betegség }\end{array}$} \\
\cline { 2 - 7 } & város járás & város & járás & város & járás \\
\hline $\begin{array}{l}\text { nem tudja } \\
\text { megitélni }\end{array}$ & $12,6 \%$ & $6,8 \%$ & $12,9 \%$ & $3,5 \%$ & $19,0 \%$ & $6,1 \%$ \\
\hline $\begin{array}{l}\text { kórházi ápolásra } \\
\text { szorul }\end{array}$ & $7,7 \%$ & $7,1 \%$ & $9,7 \%$ & $3,5 \%$ & $9,5 \%$ & $4,9 \%$ \\
\hline $\begin{array}{l}\text { ágyhoz kötött } \\
\text { otthonában }\end{array}$ & $4,4 \%$ & $1,4 \%$ & $0,0 \%$ & $4,1 \%$ & $4,8 \%$ & $1,2 \%$ \\
\hline $\begin{array}{l}\text { nem tudja } \\
\text { munkáját ellátni }\end{array}$ & $14,8 \%$ & $23,1 \%$ & $21,5 \%$ & $25,7 \%$ & $16,7 \%$ & $22,0 \%$ \\
\hline $\begin{array}{l}\text { csak korlátozza } \\
\text { munkájában }\end{array}$ & $60,7 \%$ & $61,6 \%$ & $55,9 \%$ & $63,2 \%$ & $50,0 \%$ & $65,9 \%$ \\
\hline
\end{tabular}

Forrás: Nyíregyháza Életminősége 2015

A betegek legkisebb hányada számolt be arról, hogy betegsége miatt otthonában ágyhoz kötötten kell élnie - összességében a nyíregyháziak körében ez az arány magasabb, mint a járási lakosság körében. Kórházi ellátásra a betegek kevesebb, mint egytizede szorul - a nyíregyháziakra ez a betegségkövetkezmény is jellemzőbb, mint a járásiakra. Az ágyhoz nem kötött munkaképtelenek az említés sorszámától függően a betegek egyhatodát-egynegyedét teszik ki - ez a betegségkövetkezmény a járási lakosság körében gyakoribb. Természetszerüleg a legenyhébb betegségkövetkezmény - a valamilyen szintü korlátozottság a munkában - a leggyakoribb, a betegek fele-kétharmada erről számolt be, és a járási lakosságra jellemzőbb, mint a nyíregyháziakra (2. táblázat).

3. táblázat. Az utóbbi 1 évben az adott betegséggel kezeltek aránya (\%)

\begin{tabular}{|l|c|c|c|}
\hline & város & járás & $\begin{array}{c}\text { ELEF } \\
2014\end{array}$ \\
\hline Asztma (allergiás asztma is) & 9,7 & 5,5 & 5 \\
\hline Krónikus hörghurut, bronchitisz, tüdötágulás & 6,7 & 3,2 & 4 \\
\hline Szívinfarktus, szívroham & 2,0 & 1,2 & 2 \\
\hline $\begin{array}{l}\text { Szívkoszorúér- (koronária-) megbetegedés, } \\
\text { angina }\end{array}$ & 4,2 & 4,0 & n.a. \\
\hline
\end{tabular}




\begin{tabular}{|l|c|c|c|}
\hline Magasvérnyomás-betegség (hipertónia) & 36,7 & 33,1 & 31 \\
\hline $\begin{array}{l}\text { Agyvérzés (szélütés, gutaütés, stroke, } \\
\text { agyérgörcs) }\end{array}$ & 2,0 & 1,1 & n.a. \\
\hline Reuma, ízületi gyulladás & 21,8 & 17,1 & n.a. \\
\hline Ízületi kopás (arthrózis, osteoarthritis) & 22,4 & 18,3 & 17 \\
\hline $\begin{array}{l}\text { Derékfájás vagy egyéb krónikus } \\
\text { hátgerincprobléma }\end{array}$ & 33,9 & 19,9 & 21 \\
\hline $\begin{array}{l}\text { Nyaki fájdalom vagy egyéb krónikus nyaki } \\
\text { gerincprobléma }\end{array}$ & 16,6 & 10,5 & 11 \\
\hline Cukorbetegség & 10,2 & 9,9 & 8 \\
\hline $\begin{array}{l}\text { Allergia, pl.: szénanátha, ekcéma, ételallergia } \\
\text { vagy egyéb allergia (kivéve allergiás asztma) }\end{array}$ & 18,5 & 9,1 & 12 \\
\hline Gyomor- vagy nyombélfekély & 3,5 & 3,1 & n.a. \\
\hline $\begin{array}{l}\text { Krónikus májbetegség (májcirrózis vagy } \\
\text { májzsugor) }\end{array}$ & 1,1 & 0,9 & n.a. \\
\hline $\begin{array}{l}\text { Rosszindulatú daganat (leukémia és } \\
\text { nyirokcsomódaganat/lymphoma is) }\end{array}$ & 1,2 & 1,5 & n.a. \\
\hline Erös fejfájás, pl. migrén & 22,7 & 9,4 & n.a. \\
\hline Inkontinencia, vizelettartási zavarok & 3,7 & 2,3 & n.a. \\
\hline Krónikus depresszió & 2,6 & 3,2 & 4 \\
\hline Krónikus szorongás & 3,8 & 2,5 & n.a. \\
\hline Egyéb pszichés/mentális problémák & 2,6 & 1,4 & 2 \\
\hline Magas koleszterinszint, zsíranyagcsere-zavar & 12,4 & 7,1 & 11 \\
\hline $\begin{array}{l}\text { Szabálytalan szívverés, szívritmuszavar, } \\
\text { pitvarfibrilláció }\end{array}$ & 8,5 & 6,5 & 10 \\
\hline Bármely egyéb szívbetegség & 3,9 & 3,3 & n.a. \\
\hline $\begin{array}{l}\text { Sérülés vagy baleset következtében szerzett } \\
\text { maradandó fogyatékosság }\end{array}$ & 1,5 & 1,2 & n.a. \\
\hline Csontritkulás & 9,4 & 5,3 & 6 \\
\hline
\end{tabular}

Forrás: Nyirregyháza Életminösége 2015, Európai lakossági egészségfelmérés (ELEF) 2014

Érdekes tapasztalat, hogy míg arra a kérdésre, hogy tartós vagy visszatérő betegséggel együtt él-e, a járási lakosság nagyobb arányban válaszolt igennel, mint a nyíregyházi, az egészségi problémák részletes felsorolásakor összességében a nyíregyháziak gyakrabban számoltak be arról, hogy a megkérdezés előtt eltelt 12 hónapban kezelték valamilyen betegséggel (3. táblázat) - sőt, arányuk a legtöbb egészségprobléma esetében magasabb, mint az ELEF 2014 hazai lakosságra vonatkozó adatai esetében (Statisztikai Tükör, 2015).

Migrénes fejfájás, valamint allergia miatt több, kétszeres arányban kezeltek városlakókat, mint járásiakat; a légzőszervi betegségek mindhárom kategóriájában a 
nyíregyháziak csaknem kétszeres gyakorisággal álltak kezelés alatt, mint a járásiak; a vázrendszer kopása és egyéb csontrendszerei betegségek miatt is lényegesen nagyobb arányban kaptak ellátást a nyíregyházi betegek, mint a járásiak. A fentebb említett jelentős különbségeken túl sok más egészségi probléma esetén ugyancsak a nyíregyházi betegek számoltak be nagyobb arányban a megelőző egy évben zajlott orvosi kezelésről. Az adatokból nem derül ki, hogy ez a városlakók rosszabb egészségi állapotából fakad-e - melyre csupán akkor került fókusz, amikor részletesen kérdezték -, vagy a két almintába tartozó lakosságcsoportok eltérö eséllyel férnek hozzá az egészségügyi szolgáltatásokhoz? Magyarázatként akár még az is felmerülhet, hogy a járási, tehát falvakban élő lakosság kevésbé nyíltan vállalja rosszabb fizikai állapotát, talán mert nem akarnak panaszkodónak tünni.

Betegségeik miatt a nyíregyházi lakosok 13,7\%-a, a vidéki lakosok 14,7\%-a töltött az elmúlt egy évben legalább egy éjszakát kórházban. A érintettek több mint fele ez idő alatt egyszer került kórházba (Nyíregyháza 53,4\%; járás 57,6\%), további jelentős részük kétszer került kórházba az év folyamán (Nyíregyháza 32,0\%; járás 27,3\%). A kórházba került városlakók fele összesen 1-4 éjszakát, a járási lakosság fele 1-6 éjszakát töltött kórházban. Ez utóbbi adatok ismét arra utalnak, hogy a járási lakosság egészségi állapota valamivel rosszabb, mint a nyíregyháziaké.

\section{A lakosság egészségmagatartása}

Noha az egészségmagatartás kérdése túlmutat a szubjektív egészségi állapot vizsgálatán, a korábbi hullámokról készült elemzések szerzői kitérnek erre a kérdésre is, így a jelen tanulmányban is bemutatjuk a lakosság egészségmagatartásának alakulását (Jóna és Erdei, 2012; Erdei, Fedor és Madácsi, 2014).

A kórházi ápolással kapcsolatos egészségmagatartás jellemzője lehet azok aránya, akik orvosi beutaló ellenére sem mentek el kórházban; ez mindkét almintában egyaránt 5,3\%. A távolmaradás három legmeghatározóbb oka: nem volt rá ideje (Nyíregyháza 21,7\%; járás 31,4\% - a távolmaradók százalékában), nem volt rá pénze - vélhetően a paraszolvenciára való tekintettel - (Nyíregyháza 13,0\%; járás 15,7\%), félt a mütéttől (Nyíregyháza 10,9\%; járás 11,8\%). Az egyéb okokból távolmaradók aránya volt a legmagasabb (43,5\% illetve 35,3\%), ám ez lehet gyüjtőválasz is, amely több okot rejt magában, illetve ismeretlen a tartalma, így elemzésre kevésbé alkalmas. 
13. ábra. Legutolsó látogatás a fogorvosnál, 2015

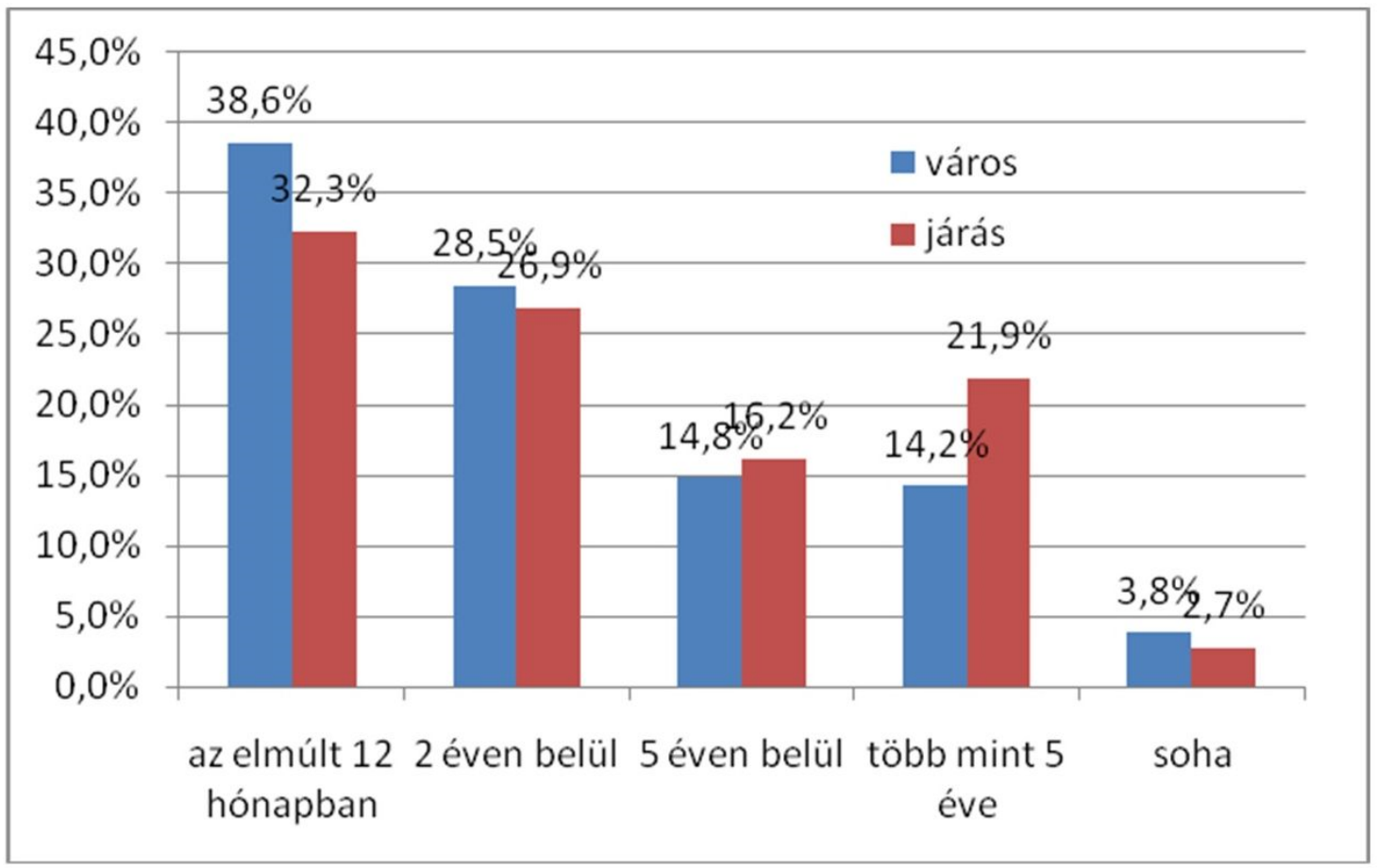

Forrás: Nyíregyháza Életminősége 2015

A saját egészségük érdekében (azaz nem családtagot kísértek vizsgálatra, kezelésre) a megkérdezettek legnagyobb csoportja egy éven belül kereste fel fogorvosát - ám ez a viszonylagos nagy csoport is a lakosság egészségmagatartásának hiányosságairól árulkodik, hiszen ez egyúttal azt is jelenti, hogy a városi lakosság 61,4\%-a, a járási lakosság 67,7\%-a egy éven belül nem járt fogorvosnál. Az Országos lakossági egészségfelmérés (OLEF) 2003-as hullámának adataiban is igen kedvezőtlen képet mutat a hazai lakosság egészségmagatartása a fogorvosi látogatásokat illetően. Az OLEF felmérést megelőző 12 hónapban nem kereste fel fogorvosát a lakosság háromötöde $(61,4 \%)$, ezen belül a nők $57,7 \%$-a, a férfiak 65,7\%-a (Hajdu, 2005).

A megkérdezettek több mint fele úgy a városi, mint a járási almintában legalább két éven belül felkereste fogorvosát. Ezen időintervallumban a városi lakosság nagyobb része járt fogorvosnál, mint a járási lakosságé. A fogorvosnál sosem járók is a városi lakosság körében képeznek nagyobb arányt.

A háziorvosát a megkérdezettek túlnyomó többsége 12 hónapon belül meglátogatta (Nyíregyháza 71,5\%; járás 71,3\%). Az alminták negyede egy évnél régebben járt háziorvosánál $(24,8 \%$, illetve $25,6 \%)$. Elenyésző azok aránya, akik sosem jártak háziorvosnál $(3,7 \%$, illetve $3,1 \%)$. A szakorvosok látogatottsága mindkét almintában lényegesen alacsonyabb, ha csak az elmúlt egy évet nézzük, illetve magasabb azok aránya, akik egy évnél régebben mentek szakorvoshoz, ahogy azoké is, akik sosem jártak szakorvosnál. A szakorvos felkeresésének intenzitásában a két alminta nem különbözik egymástól lényegesen (14. ábra). 
14. ábra. A háziorvos és a szakorvos látogatottsága, 2015

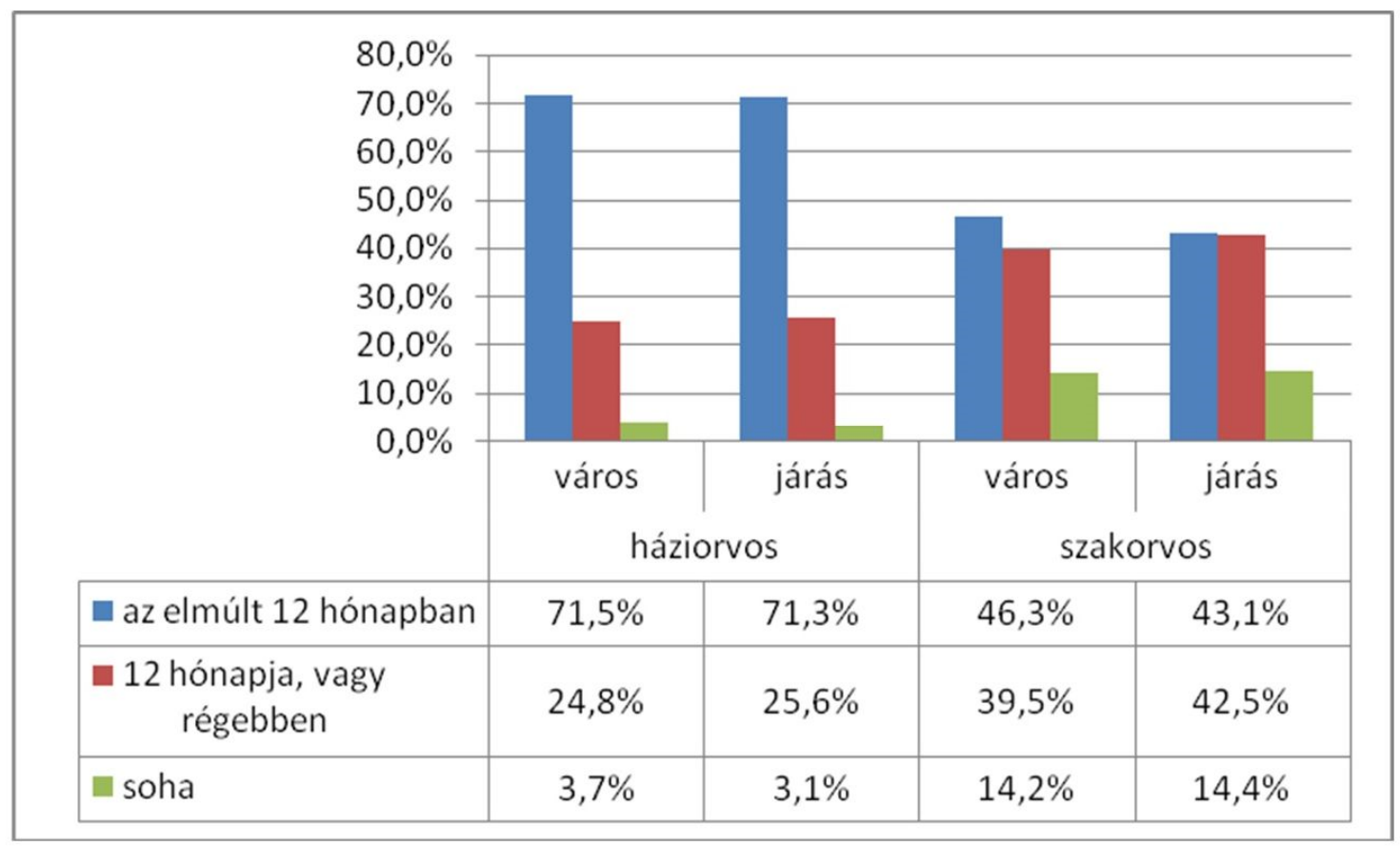

Forrás: Nyíregyháza Életminősége 2015

Az OLEF 2003-as hullámának adatai szerint a hazai lakosság három életkori csoportja (18-34 év, 35-64 év, 65+ év) változó arányban, de az életkor növekedésével arányosan növekvő mértékben kereste fel háziorvosát a lekérdezést megelőző egy évben. A háziorvost látogatók az OLEF 2003 adatai alapján a férfiak legfiatalabb korcsoportjában 72,5\%, a nők ugyanezen korcsoportjában 77,1\% (Hajdu, 2005), és mindkettő meghaladja a Nyíregyháza Életminősége 2015-ös városi, illetve járási almintájának hasonlóan viselkedő egyéneinek arányát - igaz, a férfiak csak elenyésző mértékben.

A Nyíregyháza Életminősége 2015-ös hullámának válaszadóinak tizede számolt be arról, hogy volt olyan eset, amikor nem kereste fel a szakorvost, pedig kellett volna (Nyíregyháza 12,5\%; járás 11,0\%). Ezek egynegyede azért nem ment orvoshoz, mert nem volt ideje (Nyíregyháza 25,8\%; járás 22,2\%), illetve sokan várni akartak, hátha elmúlik magától a probléma (Nyíregyháza 14,0\%; járás 20,2\%) - ez utóbbi magatartás a járási lakosságra sokkal jellemzőbb, mint a városiakra. Ugyancsak a járási lakosságra jellemzőbb ok az, hogy nem tudták megfizetni (Nyíregyháza 8,6\%; járás 13,1\%), ezzel szemben a várólisták hosszára (és/vagy a beutalók hiányára) inkább a városiak hivatkoztak (Nyíregyháza 14,0\%; járás 2,0\%).

A 4. táblázat összesíti azok arányát, akik a különböző egészségügyi szolgáltatásokat a lekérdezést megelőző 12 hónapban legalább egyszer felkeresték. Látszik, hogy legnagyobb arányban a laborvizsgálatok (és röntgen) szerepel, amelyet kizárólag háziorvosi vagy szakorvosi beutalóval lehet igénybe venni. A nyíregyháziak között magas arányban találhatunk olyanokat, akik gyógyfürdőbe mentek, illetve nem orvosi végzettségü egészségügyi szakembert kerestek fel - a járási lakosság mindkét esetben alulreprezentált. Tulajdonképpen kizárólag a 
logopédus és a pszichológus/pszichoterapeuta esetében találunk a városinál magasabb igénybevételi arányt a járási lakosságnál - amely valószínúleg az egységes pedagógiai szakszolgálat munkájával és a helyi közoktatási intézmények (óvoda, iskola) felderítő tevékenységével hozható összefüggésbe.

4. táblázat. A lekérdezést megelöző egy évben felkeresett egészségügyi szolgáltatók, 2015

\begin{tabular}{|l|c|c|}
\hline & $\begin{array}{c}\text { Nyíregyháza } \\
\mathbf{( \% )}\end{array}$ & $\begin{array}{c}\text { járás } \\
\mathbf{( \% )}\end{array}$ \\
\hline labor, röntgen & 52,3 & 51,0 \\
\hline fizioterapeuta, gyógytornász & 9,9 & 8,4 \\
\hline ápoló, nővér (kivéve az otthoni ellátás) & 4,6 & 4,4 \\
\hline védőnő (kivéve az otthoni ellátás) & 3,3 & 1,7 \\
\hline táplálkozási szakember, dietetikus & 4,1 & 2,0 \\
\hline logopédus & 0,3 & 0,5 \\
\hline gyógymasször, csontkovács, manuálterapeuta & 9,8 & 6,0 \\
\hline pszichológus vagy pszichoterapeuta & 2,6 & 3,4 \\
\hline $\begin{array}{l}\text { egyéb, nem orvosi végzettségü egészségügyi } \\
\text { szakember (pl. optometrista, fogtechnikus, } \\
\text { gyógytalpbetét-készítő) }\end{array}$ & 10,8 & 4,4 \\
\hline homeopátiás szakember & 1,6 & 1,1 \\
\hline akupunktúrás szakember & 0,8 & 0,3 \\
\hline $\begin{array}{l}\text { gyógynövényekkel foglalkozó szakember, } \\
\text { fitoterapeuta }\end{array}$ & 5,7 & 3,1 \\
\hline $\begin{array}{l}\text { más alternatív orvoslással foglalkozó } \\
\text { szakember }\end{array}$ & 1,9 & 0,8 \\
\hline Termál-, gyógyvizes kezelés & 21,7 & 8,5 \\
\hline Gyógyiszapkezelés & 2,7 & 1,5 \\
\hline Gyógybarlangkezelés & 2,3 & 0,4 \\
\hline Széndioxidszárazfürdö-kezelés & 1,1 & 0,1 \\
\hline
\end{tabular}

Forrás: Nyíregyháza Életminösége 2015 
15. ábra. A dohányzók és nemdohányzók aránya, 2015

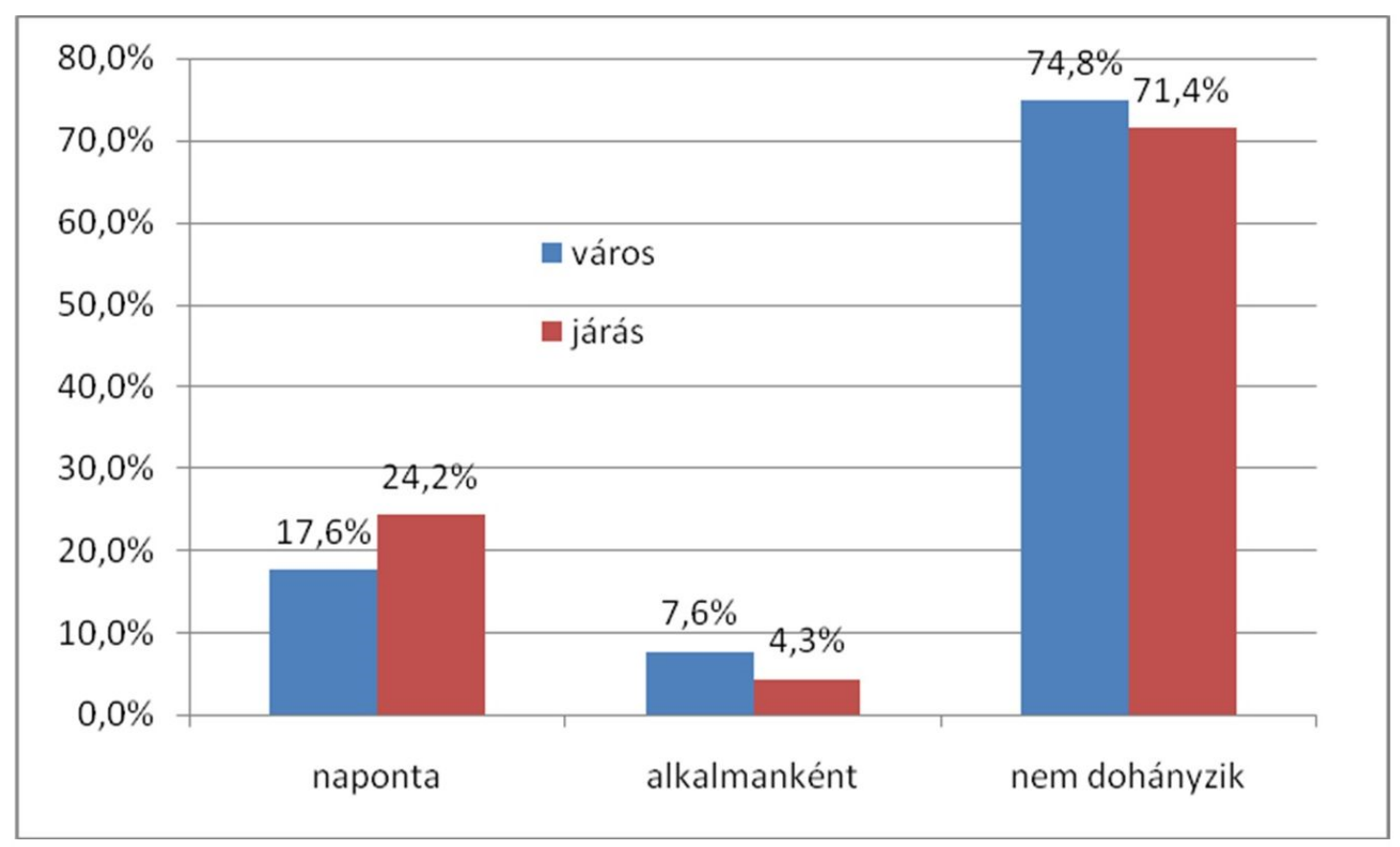

Forrás: Nyíregyháza Életminösége 2015

Az egészségmagatartás - illetve rizikómagatartás - fontos jellemzője, hogy az egyén dohányzik-e, vagy sem, illetve ha igen, milyen intenzíven, sőt, lényegében a dohányzás az egyik legkiemelkedőbb veszélyforrásnak tekinthető. A 2015-ös életminőség-kutatás adatai arra utalnak, hogy a megkérdezettek közel háromnegyede nem dohányzik. A naponta dohányzók aránya a járási lakosság körében megközelíti az egynegyedet, és ők teszik ki a járási dohányzók zömét. A városi erős dohányosok - akik naponta dohányoznak - aránya nem éri el az alminta egyötödét, és hozzájuk képest az alkalmi dohányosok aránya számottevő (15. ábra). A dohányzók aránya valamivel alatta marad az országos arányoknak (ELEF, 2014), ahol a dohányzók aránya meghaladja a $29 \%$-ot; a rendszeres dohányzók aránya $28 \%$, míg az alkalmi dohányosoké közel 2\% (Statisztikai Tükör, 2015).

A dohányzás napi intenzitását tekintve megállapítható, hogy az alacsonyabb intenzitás (napi 10 szálnál kevesebb) inkább a városlakókra jellemző, míg az ennél magasabb intenzitású dohányzás inkább a vidéki lakosságra jellemző (16. ábra). A kiemelkedő értékek $(5,10,15$ és 20 szál) a becslések szokásos jellemzőjeként jelennek meg. 
16. ábra. A naponta elszívott cigaretta mennyisége, 2015

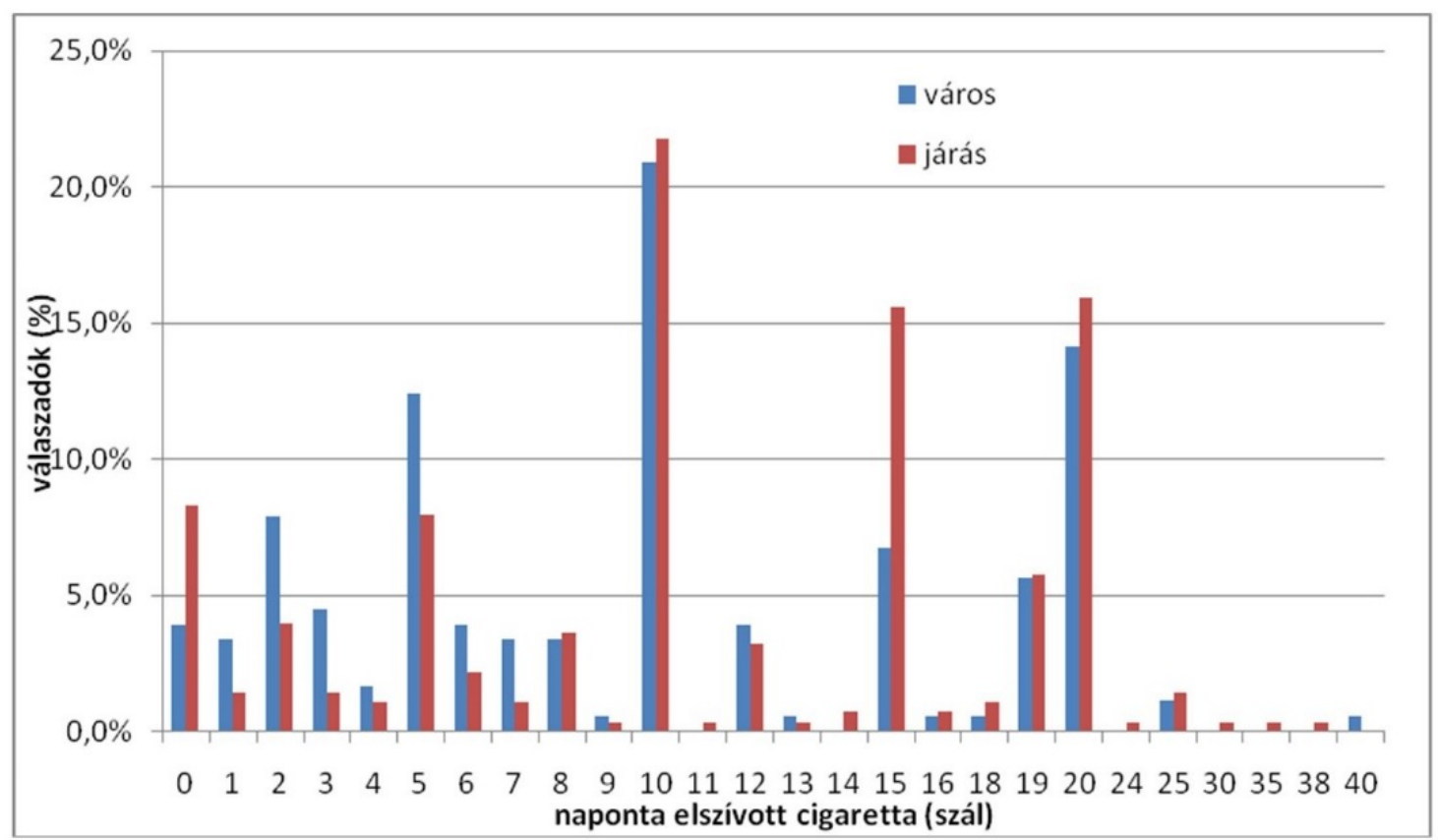

Forrás: Nyíregyháza Életminösége 2015

\section{Összegzés}

A tanulmány a Debreceni Egyetem Egészségügyi Kara és Nyíregyháza MJV Polgármesteri Hivatal Szociális Osztálya együttmüködésében megvalósuló életminőség-kutatás 2015-ös, 4. hullámának adataira támaszkodva mutatja be a nyíregyházi lakosság szubjektív egészségi állapotát befolyásoló tényezőket. Néhány további szempontból áttekinti a lakosság egészségi állapotát, illetve egészségmagatartását. A tanulmány célja elsősorban az adatközlés, illetve a panelmintán megvalósuló korábbi hullámok eredményeivel való összevetés. Új elemként az aktuális hullám kiterjed a megyeszékhelyhez tartozó járás kistelepülésein élők vizsgálatára is, így a tanulmány több helyen kitér a városi és vidéki lakosság egészség-helyzetének összehasonlítására is.

A szubjektív egészségi állapottal kapcsolatosan megállapítható, hogy az azt befolyásoló tényezők hasonlóképpen befolyásolják a lakosság egészségérzetét, mint a korábbi években. Az eltérések nem jelentősek, de az megállapítható, hogy a 2015ös mintába került személyek összességében egészségesebbnek érzik magukat, mint a korábbi hullámok panel-mintáját alkotó személyek. Az adatok alapján elmondható, hogy a szubjektív egészségi állapotot befolyásolja a megkérdezettek neme, életkora, legmagasabb iskolai végzettsége, családi állapota, továbbá az, hogy szenved-e állandó vagy visszatérő betegségektől, van-e barátja vagy sem. Összefüggés mutatható ki a megkérdezettek boldogsága és vélelmezett egészsége között is.

A tanulmány második felében a lakosság egészségi állapotára és egészségmagatartására vonatkozó kérdések adatainak bemutatására szorítkoztam. Ennek főbb tanulsága, hogy a vidéki lakosság betegségterhei magasabbnak tünnek, mint a városlakóké, miközben az egészségügyi ellátórendszerhez és szolgáltatásokhoz hozzáférésük szükebb. 


\section{Felhasznált irodalom}

1. Dahlgren G., Whitehead M. (1991): Policies and strategies to promote social equity in health. Institute of Futures Studies, Stockholm.

2. Erdei R. J-né, Fedor R. A., Madácsi E. B-né. (2014): A nyíregyházi lakosok szubjektív egészségi állapota és annak változásai. Acta Medicinae et Sociologica Vol. 5. No. 12-13: 189-206.

3. Evans R. G., Stoddart G. L. (2003) Consuming research, producing policy? Am.J.Public Health 93 (3): 371-379.

4. Fábián G., Kiss J., Patyán L., Huszti É. [szerk.] (2012): Életminőség Nyíregyházán. DE-EK, Nyíregyháza.

5. García-Muñoz T., Neuman S., Neuman T. (2014): Subjective Health Status of the Older Population: Is it related to Country-Specific Economic Development Measures? Working Papers of Bar-Ilan University. http://econ.biu.ac.il/files/economics/working-papers/2014-02.pdf Utoljára letöltve: 2015. szeptember 12.

6. Hajdu Á. (2005): Egészségügyi ellátás igénybevétele. Országos Lakossági Egészségfelmérés 2003 - kutatási jelentés. Országos Epidemiológiai Központ, Budapest.

7. Husz I. (2001): Az emberi fejlődés indexe. Szociológiai Szemle 2001/2.: 7283.

8. Huszti É. (2015a): Előszó. Acta Medicinae et Sociologica Vol. 6. No. 18-19: $5-10$.

9. Huszti É. (2015b): Mondd meg kikkel töltöd az idődet, s megmondom ki vagy. A társas támogatást nyújtó személyes kapcsolati háló néhány jellemzője és müködése a Nyíregyházi járásban. Acta Medicinae et Sociologica Vol. 6. No. 18-19: 121-144.

10. Huszti É., Patyán L., Fábián G. szerk. (2014): Életminőség Nyíregyházán 2012. Acta Medicinae et Sociologica Vol. 5. No. 12-13. Debreceni Egyetem Egészségügyi Kar Nyíregyháza.

11. Johnston D. W., Propper C., Shields M. A. (2007): Comparing Subjective and Objective Measures of Health: Evidence from Hypertension for the Income/Health Gradient. Institute for the Study of Labor (IZA), Bonn.

12. Jóna Gy., Erdei R. J-né (2012): A szubjektív egészségi állapot meghatározó tényezői Nyíregyházán. In.: Fábián G., Kiss J., Patyán L., Huszti É. [szerk.]: Életminőség Nyíregyházán. DE-EK, Nyíregyháza. 99-115.

13. Kaplan G., Baron-Epel O. (2003): What lies behind the subjective evaluation of health status? Social Science \& Medicine 56(8): 1669-1676.

14. Könczei Gy., Hernádi I. (2011): A fogyatékosságtudomány fő fogalma és annak változásai. Hipotetikus kísérlet rekonstrukcióra. Kiadó nélkül, Budapest. $\quad$ http://j1.wplanet.hu/attachments/102_K\%C3\%B6nczeiHern\%C3\%A1di_fogyatekossag_fogalom.pdf Utoljára letöltve: 2015. szeptember 12 . 
15. Malakucziné P. M. (2015): A Nyíregyházi járás települési szerkezete, demográfiai, háztartási jellemzői. Acta Medicinae et Sociologica Vol. 6. No. 18-19: 11-29.

16. Marmot M. et al. (2010): Fair Society, Healthy Lives - The Marmot Review. Strategic review of health inequalities in england post-2010. http://www.instituteofhealthequity.org/projects/fair-society-healthy-livesthe-marmot-review Utoljára letöltve: 2015. szeptember 12.

17. Pikó B. (2003): Kultúra, társadalom és lélektan. Akadémiai Kiadó, Budapest.

18. Pikó B. (2006): Orvosi szociológia. Medicina Kiadó, Budapest.

19. Statisztikai Tükör 2015/29 (2015): Európai lakossági egészségfelmérés, 2014. KSH.

20. Szigeti F., Fábián G., Takács P. (2015): Az érzelmi jóllét mérése a Nyíregyházi járás településein. Acta Medicinae et Sociologica Vol. 6. No. 18-19: 145-161.

21. Tahin T., Jeges S., Lampek K. (2000): Iskolai végzettség és egészségi állapot. Demográfia 1: 70-93.

22. Tokaji K.-né, Faragó M., Boros J. (2011): Objektíven szubjektív. Statisztikai Szemle 7-8: 786-790.

23. Ware J. E. (1986): The assessment of health status. In.: Aiken, L. H. Mechanic, D. (eds.): Application of social science of clinical medicine and health policy. Rutgers University Press, New Jersey. 204-208

\section{A szerző}

Hüse Lajos Ph.D. szociológus, főiskolai docens.

Debreceni Egyetem Egészségügyi Kar, 4400 Nyíregyháza, Sóstói u. 2-4. 